\title{
Beyond Decisional Independence: Uncovering Contributors to the Immigration Adjudication Crisis
}

\author{
Jill E. Family*
}

\section{INTRODUCTION}

The conversation about immigration adjudication has shifted from one detailing shortcomings to one addressing solutions. ${ }^{1}$ When formulating solutions, it is important to look beyond any one contributor to the crisis and to promote a holistic view. Recent proposals for immigration adjudication reform acknowledge that fixing the system requires a multi-faceted approach. ${ }^{2}$ This Article confirms the need for such an approach by showing how one popular cause of the crisis, a lack of decisional independence, only scratches the surface of what ails the immigration adjudication system. Along the way, the Article uncovers and evaluates underappreciated crisis contributors.

While decisional independence is crucial, it is vital to understand and to emphasize that achieving decisional independence will not fix all of

* Associate Professor of Law and Associate Director, Law \& Government Institute, Widener University School of Law. This Article benefited immensely from commentary provided by participants in the Immigration Law Teachers' Workshop at DePaul University School of Law, by participants in the Immigration Adjudications: Court Reform and Beyond Symposium at Penn State University Dickinson School of Law, and by colleagues in a faculty workshop at Widener University School of Law. Special thanks to Michael Hussey, Steve Legomsky, and Juliet Stumpf. Brent Johnson provided key library assistance, and Megan Zimmerman provided excellent research assistance.

1. This conversation is mostly focused on the adjudication of removal proceedings, and removal proceedings comprise the center of this Article as well. There are other kinds of immigration adjudication, however. For example, United States Citizenship and Immigration Services, a branch of the Department of Homeland Security, considers applications for immigration benefits, such as applications for legal permanent resident status. See, e.g., 8 C.F.R. § 204.1 (2010). Certain benefit determinations may be appealed to the Administrative Appeals Office, and there might be judicial review of the final order. DEPARTMENT OF Homeland SECURITY, DELEGATION TO THE BUREAU OF CitizenSHIP AND IMMIGRATION SERVICES, DELEGATION 0150.1 § 2(U) (Mar. 1, 2003) (granting authority "to exercise appellate jurisdiction over the matters described in 8 C.F.R. $\S 103.1(f)(3)(E)(i i i)$ (as in effect on Feb. 28, 2003)”). See generally 8 U.S.C. § 1252 (2006).

2. See infra note 29. 
what ails immigration adjudication. ${ }^{3}$ Focusing attention away from this one factor reveals five other substantial contributors to the shortcomings of immigration adjudication: substantive immigration law; the conflicting signals of immigration adjudication; the lack of de facto independence; the use of diversions from the system; and weakened judicial review. If these other contributors are not addressed, any reform will likely produce disappointing results.

These other contributors are causes of some of the system's deepest troubles. The harshness, complexity, and opacity of substantive immigration law create more adjudication, thus adding to huge backlogs in the system. These features of substantive immigration law also contribute to an extreme lack of lawyers in the system by making immigration law an insulated realm practiced by too few. The nature of the substantive law also creates immigration law's low esteem problem, which, in turn, affects representation rates and the quality of adjudication. A confused sense of mission-the result of conflicting signals built into the system-also contributes to the crisis. The lack of de facto independence for immigration adjudicators is stark, as adjudicators simply do not have the resources that they need. Also troublesome is a growing use of diversions from immigration adjudication. These diversions threaten to make the system accessible to only select groups. Finally, the system demands more robust judicial review, as restrictions on judicial review thwart the functioning of the system.

\section{Decisional IndePEndenCE AND THE IMMigRATION ADJUDiCATION CRISIS}

Immigration adjudication is in serious need of reform. The system is in crisis, with many diverse constituencies expressing extreme concerns. Federal judges, immigration judges, an Attorney General, the U.S.

3. Others have acknowledged the importance of thinking about immigration adjudication reform in a broad context. Professor Lenni Benson has argued that a more detailed and comprehensive understanding of judicial review of administrative immigration decision-making is a prerequisite to reforming judicial review. See Lenni B. Benson, You Can't Get There from Here: Managing Judicial Review of Immigration Cases, 2007 U. CHI. LegAL F. 405, 406. Also, Professor Margaret Taylor has argued that factors other than "place in the administrative bureaucracy" influence the quality of immigration administrative adjudication. Margaret H. Taylor, Refugee Roulette in an Administrative Law Context: The Déjà Vu of Decisional Disparities in Agency Adjudication, 60 STAN. L. REV. 475, 500 (2007). In this spirit, this Article argues that the approach to immigration adjudication reform should identify and integrate all contributors to the problems of the system. 
Department of Justice Office of Professional Responsibility, scholars, politicians, and lawyers have all expressed extreme misgivings about the system. ${ }^{4}$ This Part describes the role that decisional independence plays in the crisis. The next Part evaluates other contributors to the crisis.

The main purpose of the adjudication system is to adjudicate removal cases. In a removal case, the government charges a foreign national with an immigration violation that may result in expulsion from the United States. ${ }^{5}$ The system is comprised of immigration judges, who make up the trial level of administrative adjudication, ${ }^{6}$ the Board of Immigration Appeals, which is the administrative body that hears appeals from immigration judge decisions, ${ }^{7}$ and the federal courts of appeals, which review some of the output of the administrative adjudicatory process. $^{8}$

One major problem with the system is a lack of decisional independence at the administrative level. ${ }^{9}$ The lack of decisional independence stems from the placement of immigration judges and the Board as mere employees of the Attorney General. The entire Board exists by regulation only, and the Attorney General is ultimately in charge of hiring, firing, training, and reviewing the immigration judge corps. $^{10}$ The bureaucratic placement of the adjudicators signals dependence on a politically appointed prosecutor.

4. See Jill E. Family, A Broader View of the Immigration Adjudication Problem, 23 GEO. IMMIGR. L.J. 595, 598-611 (2009).

5. See 8 C.F.R. $\S 1003.14(a)$.

6. See id. § 1003.10.

7. See id. § 1003.1 .

8. See 8 U.S.C. § 1252 (2006).

9. Here, I adopt Professor Stephen Legomsky's focus on one type of constraint on decisional independence. Professor Legomsky has explored "the threat of personal consequences for the adjudicator" in the context of immigration adjudication. Stephen H. Legomsky, Deportation and the War on Independence, 91 CoRneLL L. ReV. 369, 389 (2006). Professor Legomsky described:

Under this constraint, the case is presumed to be one that the law clearly allows the adjudicator to decide, and there is no attempt by a superior to directly dictate the outcome of that case, but there are general threats, real or perceived, that decisions which displease an executive official could pose professional risks for the adjudicator.

Id. Professor Legomsky has argued that decisional independence is necessary, at a minimum, at some point in the immigration adjudication system to uphold the rule of law. See id. at 386, 394401, 403.

10. See 8 C.F.R. $\S 1003.1$; Authorities Delegated to the Director of the Executive Office for Immigration Review, and the Chief Immigration Judge, 72 Fed. Reg. 53,673, 53,673 (Sept. 20, 2007) (to be codified at 8 CFR pts. 1003, 1240) (explaining that immigration judges are "Department of Justice attorneys who are designated by the Attorney General to conduct such proceedings, and they are subject to the Attorney General's direction and control”). 
Establishing immigration adjudication under the thumb of the country's top prosecutor establishes a prosecutorial-focused work environment and sends a signal that the adjudicators who work for him carry a prosecutorial bent. ${ }^{11}$ This is exacerbated by the fact that the Attorney General also oversees the Office of Immigration Litigation, which represents the government in civil immigration cases before the federal courts. ${ }^{12}$ Also, the Attorney General has the ability to overrule a decision of the Board. ${ }^{13}$ Board members adjudicate with the knowledge that their boss, a politically appointed prosecutor, may take a case away from them.

The link between the supervision of the Attorney General and the lack of decisional independence is perhaps best exemplified by two controversies that developed during President George W. Bush's administration. First, there is evidence that Attorney General John Ashcroft used his power over immigration adjudication to fire ideologically selected members of the Board of Immigration Appeals. Second, the Department of Justice determined that the Bush administration used its power over the hiring of immigration adjudicators to hire new adjudicators based on their political loyalties instead of their professional qualifications.

There is evidence that, in 2003, Attorney General Ashcroft fired those Board members whose decisions were more favorable to foreign nationals. ${ }^{14}$ Ashcroft completed this downsizing as a part of an effort to streamline the work of the Board, with the objective of decreasing the Board's backlog of 56,000 cases. ${ }^{15}$ The streamlining program also prevented the remaining Board members from giving reasons for their decisions in a majority of cases. ${ }^{16}$ The President of the National Association of Immigration Judges, Dana Leigh Marks, has explained that immigration judges saw the Board firings as politically motivated

11. See Am. Bar Ass'n, Reforming the Immigration System: Proposals to Promote INDEPENDENCE, FAIRNESS, EFFICIENCY, AND PROFESSIONALISM IN THE ADJUDICATION OF REMOVAL CASES, at ES-44 (2010), available at http:/www.americanbar.org/content/dam/aba /migrated/Immigration/PublicDocuments/aba_complete_full_report.authcheckdam.pdf [hereinafter ABA STUDY].

12. Dana Leigh Marks, An Urgent Priority: Why Congress Should Establish an Article I Immigration Court, 13 BENDER's IMMIGR. BuLL. 3, 3-4, 10-11 (2008).

13. See 8 C.F.R. $\S$ 1003.1(h) (detailing when the Board shall refer cases to the Attorney General, including when the Attorney General so requests).

14. See Peter J. Levinson, The Facade of Quasi-Judicial Independence in Immigration Appellate Adjudications, 9 BENDER's IMMIGR. BuLl. 1154, 1154 (2004) (analyzing case data surrounding the Board member firings); see also Legomsky, supra note 9, at 376.

15. See Family, supra note 4, at 605; Legomsky, supra note 9, at 375-76.

16. Family, supra note 4, at 605 . 
and serving as a warning to immigration judges. ${ }^{17}$ Immigration Judge Marks called the Attorney General's actions "selective downsizing" and noted the "chilling effect" of the firings. ${ }^{18}$ As employees of the Attorney General, immigration judges felt political pressure on their rulings.

A politicized hiring process has also highlighted the fragility of immigration adjudication. The U.S. Department of Justice Office of Professional Responsibility and the U.S. Department of Justice Inspector General issued a report detailing the unlawful politicization of hiring for immigration judge positions during the Bush administration. ${ }^{19}$ Immigration judges fill career civil service positions. ${ }^{20}$ These are not purely political positions. ${ }^{21}$ The report concluded that members of the Bush administration violated civil service laws and departmental policy in selecting candidates for immigration judge positions based on political ties and recommendations rather than based on professional qualifications. $^{22}$ At times, individuals were hired based on political recommendations without interviews or any vetting by career immigration adjudication specialists in the Department. ${ }^{23}$ Additionally, those appointed with immigration law experience "were prosecutors or held other immigration enforcement jobs," as opposed to experience representing the interests of foreign nationals. ${ }^{24}$ Hiring adjudicators based on political loyalties sent a message to all adjudicators that those who acted in-step with the Attorney General would be rewarded.

A lack of decisional independence is one problem facing the immigration adjudication system. Recent proposals to fix this adjudication system envision the achievement of decisional independence as at least a key component of the solution to the immigration adjudication problem. ${ }^{25}$ Some proposals which advocate for

17. See Marks, supra note 12, at 11 n.52.

18. Id. at $11,14$.

19. See U.S. DeP'T of Justice, An InVEstigation of Allegations of Politicized HiRing

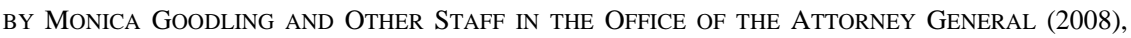
available at http://www.justice.gov/opr/goodling072408.pdf.

20. Id. at 70 .

21. Id. at $11-15$.

22. See id. at $69,115$.

23. Id. at 75, 81-82, 88-90, 105 .

24. Amy Goldstein \& Dan Eggen, Immigration Judges Often Picked Based on GOP Ties; Law Forbids Practice; Courts Being Reshaped, WASH. Post, June 11, 2007, at A1.

25. See ABA STUDY, supra note 11, at ES-43 to -44; AM. IMMIGRATION LAWYERS Ass'N, ISSUE PAPER: THE IMPORTANCE OF INDEPENDENCE AND ACCOUNTABILITY IN OUR IMMIGRATION COURTS (2006), available at http://www.aila.org/content/default.aspx?docid=8382; APPLESEED, ASSEMBLY LINE INJUSTICE: BLUEPRINT TO REFORM AMERICA's IMMIGRATION COURTS 35 (2009), available at http://www.appleseednetwork.org/Portals/0/Documents/Publications/Assembly\%20Line 
decisional independence call for the creation of an Article I immigration court, which would remove immigration adjudicators from the supervision of the Attorney General. ${ }^{26}$ Another proposal would achieve the same goal through the creation of an independent executive agency to house immigration adjudication. ${ }^{27}$ Another promotes increased job security for immigration judges, along with the creation of an Article III immigration court as a path toward decisional independence. ${ }^{28}$

This Article is not at odds with these proposals for reform, as they acknowledge that creating decisional independence is not the only necessary fix. $^{29}$ This Article, however, deconstructs the crisis in a way that reveals different ingredients to the crisis recipe, as well as analyzes some previously recognized contributors in different contexts.

\section{BEYOND DECISIONAL INDEPENDENCE}

This Part looks beyond decisional independence to identify and examine five other contributors to the unsatisfactory state of immigration adjudication. In addition to establishing decisional independence, successful immigration adjudication reform is linked to the state of substantive immigration law, resolving the conflicting signals of immigration adjudication, the creation of de facto independence for

\%20Injustice.pdf; Jaya Ramu-Nogales Et al., RefugeE Roulette: Disparities in Asylum AdJUDiCATION AND PROPOSALS FOR REFORM 103-04 (2009); Stephen H. Legomsky, Restructuring Immigration Adjudication, 59 DUKE L.J. 1635, 1677, 1689-92 (2010); Marks, supra note 12, at 2021.

26. See ABA STUDY, supra note 11, at ES-47 to -48; APPLESEED, supra note 25, at 35; RAMJINogALES ET AL., supra note 25, at 103-04; Marks, supra note 12, at 16-17.

27. AM. IMMIGRATION LAWYERS ASs'N, supra note 25.

28. Legomsky, supra note 25, at 1640, 1686-87.

29. See ABA STUDY, supra note 11, at ES-54 to -71 (proposing changes to substantive immigration law, recognizing the need for higher representation rates, advocating for wider judicial review, arguing for curtailed use of some diversions from administrative adjudication and emphasizing that immigration adjudicators must have sufficient resources and training, in addition to structural reform); AM. IMMIGRATION LAWYERS ASS'N, supra note 25 (pointing out a lack of resources); APPLESEED, supra note 25, at 10-11, 17, 29 (recognizing the need for more resources, the role of prosecutorial discretion, and the lack of representation); RAMJI-NOGALES ET AL., supra note 25, at 100-18 (advocating the creation of an Article I immigration court to depoliticize the asylum adjudication process but also calling for increased professionalization and for amending the standard of review of Board decisions, among other things); Legomsky, supra note 25, at 1639-40 (acknowledging that "restructuring, although essential to reform of the immigration adjudication system, is not sufficient" and arguing that the principal causes of the crisis are "severe underfunding, reckless procedural shortcuts, the inappropriate politicization of the process, and a handful of adjudicators personally ill-suited to the task"); Marks, supra note 12, at 14 (describing a "persistent lack of resources”). 
immigration adjudicators, the proper use of diversions from immigration adjudication, and a stronger role for the federal courts.

\section{A. The Limits of Decisional Independence: Lessons from the Veterans Court}

The Court of Appeals of Veterans Claims (Veterans Court) provides an example of how the institution of decisional independence can lead to disappointing reform. From the lessons of the Veterans Court, we can see that meaningful immigration adjudication reform depends not just on the adoption of one particular structural framework, but on a more holistic approach that more broadly emphasizes other contributing characteristics in addition to decisional independence. ${ }^{30}$ Incorporating the Article I structure by itself, for example, may improve decisional independence, ${ }^{31}$ but may not address other problems plaguing the system.

The experience of the Veterans Court is evidence that a prodecisional independence structural change is not a guaranteed panacea. ${ }^{32}$ Over twenty years ago, Congress responded to calls of dissatisfaction with the adjudication of veterans' benefits claims by creating the Veterans Court. ${ }^{33}$ Before this reform, applications for veterans' benefits were simply not subject to review beyond the decision of the administrative Board of Veterans Appeals. ${ }^{34}$ This lack of review led to concerns about fairness; that veterans deserved a neutral body to hear

30. There are doubts about the effectiveness of broad bureaucratic organizations generally. Jeffrey Manns, Legislation Comment, Reorganization as a Substitute for Reform: The Abolition of the INS, 112 YALE L.J. 145, 146 (2002) (explaining that "the literature on [bureaucratic] reorganizations casts doubt on their efficacy as a vehicle for reform").

31. It is beyond the scope of this Article to evaluate whether a change in structure will, in fact, improve decisional independence.

32. An Article I Immigration Court, consisting of both trial and appellate levels, with available judicial review, would look structurally different than the veterans' benefits adjudication process. A veteran files a claim for benefits first with a regional office of the Veterans Administration. Michael P. Allen, The United States Court of Appeals for Veterans Claims at Twenty: A Proposal for a Legislative Commission to Consider Its Future, 58 CATH. U. L. REV. 361, 365-66 (2009). If that claim is denied, there is some opportunity for reconsideration within the regional office, followed by an appeal to the Board of Veterans Appeals, if desired. Id. at 366. An appeal from the Board of Veterans Appeals lands at the Article I Court of Appeals for Veterans Claims. Id. at 367-68. From there, a limited appeal right exists to the Court of Appeals for the Federal Circuit. Id. at 368. Analysis of the Article I Court of Appeals for Veterans Claims is instructive here, however, because it is an example of pro-independence reform that has failed to quiet calls for further adjudication reform.

33. See id. at $364,375-76$.

34. See id. at 375 . 
their appeals and to issue better quality decisions. ${ }^{35}$ To improve the process, Congress created the Article I Veterans Court to hear appeals from the administrative Board of Veterans Appeals and established limited federal court jurisdiction over the decisions of the Article I court. $^{36}$ The Article I court is staffed by at most nine judges serving fifteen-year terms. ${ }^{37}$ These judges are appointed by the President and confirmed by the Senate. ${ }^{38}$

Even after the creation of the Article I Veterans Court, the adjudication of veterans' cases is still highly controversial and marked by numerous observed shortcomings. ${ }^{39}$ Critics assert that the Veterans Court is not truly independent, that it faces crippling caseloads, and that its existence has not improved the quality of agency adjudication. ${ }^{40}$ These shortcomings are serious enough to have led to a call for a legislative commission to study the future of the court. ${ }^{41}$

Concerns surround the relationship between the Veterans Court and the Veterans Administration. These concerns focus on whether the Veterans Court is truly independent. As one observer put it, "The Department continues to treat the Veterans Court in a manner inconsistent with an independent adjudicative body." 42 This observer described a scenario where the agency, unhappy with a decision of the Veterans Court, ordered its own adjudicators to stay any cases raising the same issue rather than to adjudicate those cases under the unpopular decision of the independent Veterans Court. ${ }^{43}$ The agency's behavior effectively nullified the decision of the Veterans Court. ${ }^{44}$ Another observer wrote that "the [Veterans Court] does not exhibit the will to compel the [Veterans Administration] to deliver timely and accurate

\footnotetext{
35. Id. at $375-76$.

36. 38 U.S.C. $\S \S 7251-7252,7292$ (2006).

37. 38 U.S.C. § 7253(a), (h), (i) (2006 \& Supp. II 2008).

38. 38 U.S.C. $\S 7253(\mathrm{~b})(2006)$.

39. Some acknowledged advancements have been credited to the Article I court, but the overall perspective is that the system still is not satisfactory. The Article I court is credited with the development of a body of case law concerning veterans' benefits. Allen, supra note 32, at 372-73. The formal independence of the court from the Veterans Administration has also been recognized, along with an increased perception of fairness (at least when compared with the lack of review that existed before). Id. at 373-76. Finally, the Article I court is credited with some improvement of the quality of decisions issued by the Veterans Administration. Id. at 376-77.

40. See id. at 377-87.

41. Id. at 387-90.

42. Id. at 381 .

43. Id. at 381-83.

44. See id.
} 
service to those who present claims." ${ }^{45}$ This analysis describes a Veterans Court habit of the "painless remand," where the Veterans Administration does not face a "meaningful consequence" for errors in adjudication. ${ }^{46}$ In other words, the Article I court issues a weak remand instead of a strong reversal. ${ }^{47}$ This analysis questions the true independence of the Article I court by labeling it "an extension of [the] in-house review mechanism." ${ }^{48}$

As far as caseloads, concerns surround the length of time it takes for the Veterans Court to adjudicate an appeal. In 2007, the median time to adjudicate a case at the Article I court was 416 days. ${ }^{49}$ The wait is at least partially due to a huge caseload at the Veterans Court, which has led to the use of single-judge opinions. ${ }^{50}$

The creation of the Article I Veterans Court also has not diminished criticism of the quality of the benefits adjudication process before the administrative agency. In January 2010, the television show 60 Minutes broadcasted a segment titled, "Veterans' Benefit Frustrations."51 The segment highlighted the large backlog of claims awaiting initial adjudication, examined the complicated nature of the application process, and questioned the quality of adjudication. ${ }^{52}$ The segment reported on a motto for the process created by benefit applicants: "Delay, Deny and Hope that I Die."

Whether some disagree with these critiques of the Article I Veterans Court, it is important to recognize that the reform of creating an Article I Veterans Court, complete with the promise of decisional independence, did not end concerns about the quality of veterans' benefits adjudication. Even an independent Article I court can face challenges asserting a lack of independence and a lack of efficiency, and the creation of the Article I

45. James T. O’Reilly, Burying Caesar: Replacement of the Veterans Appeals Process is Needed to Provide Fairness to Claimants, 53 ADMIN. L. REV. 223, 228 (2001).

46. Id. at 233.

47. See Michael P. Allen, Significant Developments in Veterans Law (2004-2006) and What They Reveal About the U.S. Court of Appeals for Veterans Claims and the U.S. Court of Appeals for the Federal Circuit, 40 U. MICH. J.L. REFORM 483, 528-29 (2007) (discussing how the use of remands over reversals damages veterans’ perceptions of the Veterans Court).

48. O’Reilly, supra note 45, at 248.

49. Allen, supra note 32, at 377.

50. See Allen, supra note 47, at 515-16.

51. 60 Minutes: Veterans' Benefit Frustrations (CBS television broadcast Jan. 3, 2010), available at http://www.cbsnews.com/video/watch/?id=6050247n.

52. Id.

53. Id. 
Veterans Court has not eliminated concerns about the quality of agency adjudication.

Some of the complaints raised about the adjudication of veterans' claims post-reform are strikingly similar to some of those currently raised about immigration adjudication pre-reform. In both areas, concerns arise about whether the adjudication system incorporates too much rubber-stamping and too little meaningful independent review, about backlogs, and about the quality of the output of the system. While these are different administrative systems, the experience of the Veterans Court should at least serve as a warning that administrative adjudication reform is more dynamic and intricate than it may seem.

In fact, even the Article I Tax Court is not immune to charges of bias or incomplete independence. ${ }^{54}$ While sometimes cited as a model for immigration adjudication reform, ${ }^{55}$ it must be acknowledged that the Tax Court does have its critics. Again, whether the Tax Court is actually biased or is not exercising true independence from the executive branch is not as important here as is recognizing that creation of a formally independent court alone does not necessarily eliminate concerns about adjudication. Perhaps one source of (at least) perceived Tax Court bias is that the complexity of substantive tax law works in the government's favor and against a pro se litigant. ${ }^{56}$ This illustrates that the reputation of administrative adjudication depends on more than its decisional independence.

If creating a structure that allows for decisional independence is not a guaranteed fix, other factors must affect the state of an adjudication system. Those other factors will vary from administrative system to administrative system. This Article focuses on factors, beyond a lack of decisional independence, that detrimentally affect the immigration adjudication system. A broader approach to reform that engages these other contributors will boost the chances of successful reform. Any reform must consider all of the roadblocks to improved adjudication, in

54. See, e.g., Deborah A. Geier, The Tax Court, Article III, and the Proposal Advanced by the Federal Courts Study Committee: A Study in Applied Constitutional Theory, 76 CORNELL L. REV. 985, 999-1000 (1991) (describing that a possible unconscious bias may exist among Tax Court judges); David Laro, The Evolution of the Tax Court as an Independent Tribunal, 1995 U. ILL. L. REV. 17, 25-28 (responding to charges of pro-government Tax Court bias); Leandra Lederman, Tax Appeal: A Proposal to Make the United States Tax Court More Judicial, 85 WASH. U. L. REV. 1195, 1212 (2008) (discussing a perception of bias); James Edward Maule, Instant Replay, Weak Teams, and Disputed Calls: An Empirical Study of Alleged Tax Court Judge Bias, 66 TENN. L. REV. 351 (1999) (evaluating allegations of Tax Court bias).

55. See, e.g., Marks, supra note 12, at 4, 15.

56. Laro, supra note 54, at 26-27. 
addition to correcting problems presented by a lack of decisional independence.

\section{B. Other Contributors to the Immigration Adjudication Crisis}

What types of reforms, in addition to advances in decisional independence, are necessary to improve immigration adjudication? Five additional problems contribute to the immigration adjudication crisis: substantive immigration law; the conflicting signals of immigration adjudication; the lack of de facto independence; the use of diversions from the system; and weakened judicial review. ${ }^{57}$

\section{Substantive Immigration Law: Harshness, Complexity, and Opacity}

Even if immigration adjudicators achieve decisional independence, the adjudication system would still be limited by the state of substantive immigration law. Many of the problems with the immigration adjudication system can be traced back to the harshness, complexity, and opacity of substantive immigration law. ${ }^{58}$ Specifically, the state of the substantive law contributes to the huge backlogs in the system, the extreme lack of lawyers in the system, and immigration law's esteem problem. $^{59}$ A new structure, such as an Article I immigration court, may yield disappointing results if the issues plaguing substantive immigration law are transferred to the new venue. ${ }^{60}$

57. There are well-documented inconsistencies in the adjudication of asylum cases. See generally RAMJI-NOGALES ET AL., supra note 25. I do not address these inconsistencies because I view them as a byproduct of a troubled system (as are poor quality decisions), rather than as causes of the crisis. The five problems discussed here are inputs rather than outputs.

58. The ABA Study acknowledges the link between substantive immigration law, including the way it is enforced, and the adjudication system. See ABA STUDY, supra note 11, at ES-19 to -26. The Study dedicated a whole Part to the Department of Homeland Security which discusses how the severity of certain provisions-specifically the aggravated felony, crime of moral turpitude, unlawful presence, and detention provisions - and the lack of prosecutorial discretion create the need for more adjudication. Id. This Article similarly recognizes the interdependence between substantive law and the adjudication system but uncovers other evidence and manifestations of interdependence and presents a more focused analysis of the connections.

59. See infra Part III.B.1.d.

60. Others have acknowledged links between substantive immigration law and immigration adjudication. See Lenni B. Benson, Breaking Bureaucratic Borders: A Necessary Step Toward Immigration Law Reform, 54 ADMIN. L. REV. 203, 205-09 (2002) (uncovering “process borders" in adjudication that hinder those wishing to access the benefits afforded by substantive immigration law); Lenni B. Benson, Making Paper Dolls: How Restrictions on Judicial Review and the Administrative Process Increase Immigration Cases in the Federal Courts, 51 N.Y.L. SCH. L. REV. 37, 41-56, 64-68 (2006-2007) (pointing out the role of broad removability grounds, increased 
Substantive immigration law is "complex, obtuse, and, at times, unintelligible." ${ }^{\prime}$ This Section will describe the harshness, complexity, and opacity of immigration law. With a better understanding of these qualities, this Section will then explicitly link these qualities to the immigration adjudication crisis.

\section{a. Harshness and Complexity: Inadmissibility and Deportability Grounds}

One main task of substantive immigration law is to establish categories of behavior or characteristics that will prevent an individual's admission into the United States, result in an individual's deportation from the United States, or both. The inadmissibility and deportability grounds are broad, strict, confusing, ${ }^{62}$ and unforgiving. ${ }^{63}$ One inadmissibility ground and one deportability ground are discussed here to illustrate the harshness and complexity of substantive immigration law. These examples are typical of the severity and intricacy of immigration law.

One inadmissibility ground denies legal entry to anyone "convicted of, or who admits having committed, or who admits committing acts which constitute the essential elements of ... a violation of (or a conspiracy or attempt to violate) any law or regulation of a State, the

enforcement, the limited availability of relief, the limits on judicial review, and the increased use of detention in contributing to the increase in the number of immigration cases in the federal courts) [hereinafter Benson, Making Paper Dolls]; David A. Martin, Mandel, Cheng Fan Kwok, and Other Unappealing Cases: The Next Frontier of Immigration Reform, 27 VA. J. INT'L L. 803, 805 (1987) (identifying the importance of the adjudication system in the potential success of substantive reforms); Gerald L. Neuman, Discretionary Deportation, 20 GEO. IMMIGR. L.J. 611, 621 (2006) (connecting the degree of discretion afforded by the substantive law to the complexity of adjudication); Brian G. Slocum, Courts vs. the Political Branches: Immigration "Reform" and the Battle for the Future of Immigration Law, 5 GEO. J.L. \& PUB. POL’Y 509, 526 (2007) (describing adjudication reform as "limited" and arguing that "[t]he most pressing injustices in immigration law stem from the extremely harsh substantive laws passed by Congress"); Leon Wildes, The Need for a Specialized Immigration Court: A Practical Response, 18 SAN DIEGO L. REV. 53, 57 (1980) (characterizing a proposal for structural reform as "a mere upgrading of the stature of immigration judges, with no assurance whatsoever that the alien will receive any tangible benefit”).

61. Kevin R. Johnson, Ten Guiding Principles for Truly Comprehensive Immigration Reform: A Blueprint, 55 WAYNE L. REV. 1599, 1637 (2009).

62. Justice Alito has emphasized the intimidating task of determining whether a particular criminal offense renders someone deportable. Padilla v. Kentucky, 130 S. Ct. 1473, 1489 (2010) (Alito, J., concurring) (referring to a "dizzying paragraph" in an immigration law guidebook that attempts to explain whether a particular offense renders someone deportable).

63. "While once there was only a narrow class of deportable offenses and judges wielded broad discretionary authority to prevent deportation, immigration reforms over time have expanded the class of deportable offenses and limited the authority of judges to alleviate the harsh consequences of deportation.” Id. at 1478. 
United States, or a foreign country relating to a controlled substance.”64 There are no exceptions, and there is no requirement of a conviction. ${ }^{65}$

Two potential waivers may be available, but the availability of those waivers is extremely narrow. One waiver, which is not the focus here, is only available to temporary visitors, and the authority to grant the waiver is left wholly to the discretion of the executive branch. ${ }^{66}$ The other waiver, which is the focus, applies to those seeking to be admitted as a lawful permanent resident ("green card" status) ${ }^{67}$ This lawful permanent resident waiver is extremely complex and is difficult to summarize. ${ }^{68}$

64. 8 U.S.C. $\S 1182(a)(2)(A)(i)(I I) ~(2006)$ (emphasis added). A conviction for immigration purposes includes a guilty plea. Id. $\S 1101(\mathrm{a})(48)(\mathrm{A})(\mathrm{i})$.

65. See id. § 1182(a)(2)(A)(i)-(ii).

66. Id. § 1182(d)(3)(A).

67. Id. $\S 1182(\mathrm{~h})$.

68. To appreciate the type of statutory construction that is usual in immigration law, I reproduce the entire statutory section here. At the very least, the immigration laws could benefit from a restyling effort.

(h) Waiver of subsection (a)(2)(A)(i)(I), (II), (B), (D), and (E)

The Attorney General may, in his discretion, waive the application of subparagraphs (A)(i)(I), (B), (D), and (E) of subsection (a)(2) of this section and subparagraph (A)(i)(II) of such subsection insofar as it relates to a single offense of simple possession of 30 grams or less of marijuana if-

(1)(A) in the case of any immigrant it is established to the satisfaction of the Attorney General that-

(i) the alien is inadmissible only under subparagraph (D)(i) or (D)(ii) of such subsection or the activities for which the alien is inadmissible occurred more than 15 years before the date of the alien's application for a visa, admission, or adjustment of status,

(ii) the admission to the United States of such alien would not be contrary to the national welfare, safety, or security of the United States, and

(iii) the alien has been rehabilitated; or

(B) in the case of an immigrant who is the spouse, parent, son, or daughter of a citizen of the United States or an alien lawfully admitted for permanent residence if it is established to the satisfaction of the Attorney General that the alien's denial of admission would result in extreme hardship to the United States citizen or lawfully resident spouse, parent, son, or daughter of such alien; or

(C) the alien is a VAWA self-petitioner; and

(2) the Attorney General, in his discretion, and pursuant to such terms, conditions and procedures as he may by regulations prescribe, has consented to the alien's applying or reapplying for a visa, for admission to the United States, or adjustment of status.

No waiver shall be provided under this subsection in the case of an alien who has been convicted of (or who has admitted committing acts that constitute) murder or criminal acts involving torture, or an attempt or conspiracy to commit murder or a criminal act involving torture. No waiver shall be granted under this subsection in the case of an alien who has previously been admitted to the United States as an alien lawfully admitted for permanent residence if either since the date of such admission the alien has been convicted of an aggravated felony or the alien has not lawfully resided continuously in the United States for a period of not less than 7 years immediately preceding the date of initiation of proceedings to remove the alien from the United States. No court shall have jurisdiction to review a decision of the Attorney General to grant or deny a waiver under 
Eligibility for this lawful permanent resident waiver begins with a relatively simple, but harsh, condition. This waiver is only available to those inadmissible under the controlled substance ground, described above, whose violation consisted of "a single offense of simple possession of 30 grams or less of marijuana." "69 Any other type of drug violation renders the individual ineligible for the waiver, and thus, inadmissible.

In the next step of the waiver analysis, the theme remains harsh, but also increases in complexity. Even if an individual falls under the simple possession of thirty grams or less of marijuana category, the waiver is still not guaranteed. The waiver is available only if (A) the violation occurred more than fifteen years before the application for admission, and the admission of the foreign national "would not be contrary to the national welfare, safety, or security of the United States," and the foreign national "has been rehabilitated;" or (B) the foreign national is the spouse, parent, son or daughter of a United States citizen or a lawful permanent resident and the executive branch determines that the "denial of admission would result in extreme hardship" to the qualifying relative. $^{70}$ But the statutory requirements do not end there. Even if the individual can show that he or she meets $(\mathrm{A})$ or $(\mathrm{B})$ above, the issuance of the waiver is wholly within the discretion of the executive branch. ${ }^{71}$ Also, even if the individual can show that he or she meets (A) or (B) above, the waiver is not available if the applicant was previously admitted $^{72}$ in lawful permanent resident status and (1) has been convicted of an aggravated felony or (2) has not continuously resided in the United States for at least seven years. ${ }^{73}$

Thus, the inadmissibility ground and its accompanying lawful permanent resident waiver are both harsh and complex. The inadmissibility ground holds these qualities because it sweeps in any

Id.

this subsection.

69. Id.

70. Id. § 1182(h)(1)(A)-(B) (emphasis added). There is a third possibility, (C), which applies if the applicant for the waiver is self-petitioning under the Violence Against Women Act. Id. $\S 1182(\mathrm{~h})(1)(\mathrm{C})$.

71. Id. § 1182(h)(2).

72. Litigation over the use of the term admitted further illustrates the complexity of the law. The Fifth Circuit has concluded that use of the term admitted does not include those whose status was adjusted to lawful permanent residence at some point after an original admission under some other status. Martinez v. Mukasey, 519 F.3d 532, 544 (5th Cir. 2008).

73. 8 U.S.C. § 1182(h)(2) (emphasis added) (following section 1182(h)(2), but without carrying its own numerical indicator). The statute also bars against granting a waiver to anyone convicted of, or who has admitted committing, acts that constitute serious crimes, like murder. Id. 
drug violation, even if there was never a conviction. The waiver holds these qualities because it only exists within the discretion of the executive, even if an applicant fits into its narrow reach (it is restricted only to possession of a small amount of marijuana) and can satisfy a labyrinth of conditions.

While the text of this drug violation waiver is mind-boggling, the text of the aggravated felony deportability ground, in contrast, consists of one simple sentence. It states that "any alien who is convicted of an aggravated felony at any time after admission is deportable." ${ }^{74}$ This seeming simplicity is deceptive, however, because the statute contains an elaborate and intricate definition of the term aggravated felony. This definition consists of a long list of broad categories of offenses that qualify, for immigration purposes, as an aggravated felony, no matter if the offense was aggravated or a felony. ${ }^{75}$

The aggravated felony label is harsh, in part, because of the deception surrounding the label. To label an individual an aggravated felon paints an ominous picture, when in reality the offense supporting the label could be relatively minor. The ramifications of the deception magnify its harshness. Once the label is attached, aggravated felons are not eligible for most forms of relief from removal, ${ }^{76}$ are subject to mandatory detention, ${ }^{77}$ and face a permanent bar to returning to the United States after removal. ${ }^{78}$ The provision is also harsh because it applies without time limit - the offense may occur at any time after admission, and the individual's connections to the United States do not matter.

The aggravated felony ground of deportability is also complex. Adjudicators expend much effort determining whether a conviction under a particular statute fits within the statutory definition of an aggravated felony. For example, the statutory definition of an aggravated felony includes "a crime of violence," as defined under other

74. Id. § 1227(a)(2)(A)(iii).

75. Id. § 1101(a)(43). For example, a "drug trafficking crime" is an aggravated felony. Id. $\S$ 1101(a)(43)(B). The government has argued that two state law misdemeanor possession offenses constitute a drug trafficking crime, but the Supreme Court disagreed. Carachuri-Rosendo v. Holder, 130 S. Ct. 2577, 2589-90 (2010).

76. See 8 U.S.C. § 1229b(a)(3) (providing that an individual's removal cannot be cancelled if he or she has "been convicted of any aggravated felony"); id. § 1229c(a)(1) (providing that an aggravated felon may not be permitted to depart the United States at his own expense in lieu of removal proceedings).

77. See id. § 1226(c)(1)(B).

78. See id. § 1182(a)(9)(A)(ii). 
federal law. ${ }^{79}$ A crime of violence includes "an offense that has as an element the use, attempted use, or threatened use of physical force against the person or property of another." ${ }^{\text {80 }}$ Particular statutes of conviction must be compared against that definition to determine whether the statute of conviction encompasses the requisite mental state. In one thread of this type of inquiry, the Supreme Court ultimately determined that a DUI statute that requires either no mens rea or only a showing of negligence does not qualify as a crime of violence and thus cannot support the aggravated felony label. ${ }^{81}$

Once a deportability ground attaches (for example, an offense is determined to be an aggravated felony), there is a narrow avenue of potential relief from deportation. The narrowness of this relief also exhibits the harshness and complexity of immigration law. A close look at the major form of relief from removal, called Cancellation of Removal, shows that it is very complex to apply, as well as harsh in that it sets the bar to relief high and provides little to no room to consider rehabilitation or other equitable considerations. ${ }^{82}$

The statute permits cancellation under two main routes. The first is for those individuals who have already achieved permanent resident status. Under Cancellation of Removal part (a), an individual's removal may be cancelled if (1) the individual has been "lawfully admitted for permanent residence for not less than 5 years," (2) the individual "has resided in the United States continuously for 7 years after having been admitted in any status," and (3) the individual "has not been convicted of any aggravated felony."83 The second route to cancellation is open to both permanent residents who cannot meet the requirements of part (a) and to those without that status. Under Cancellation of Removal part (b), an individual's removal may be cancelled if (1) the individual "has been physically present in the United States for a continuous period of not less than 10 years," (2) the individual "has been a person of good moral character during such period," (3) the individual has not been convicted of certain crimes, and (4) the individual "establishes that removal would result in exceptional and extremely unusual hardship" to the individual's spouse, parent, or child, but only if that qualifying relative is a citizen of the United States or is a lawful permanent resident of the United States. ${ }^{84}$

\footnotetext{
79. Id. § 1101(a)(43)(F).

80. 18 U.S.C. § $16(\mathrm{a})$.

81. Leocal v. Ashcroft, 543 U.S. 1, 11 (2004).

82. See 8 U.S.C. $\S 1229 b$.

83. Id. § $1229 \mathrm{~b}(\mathrm{a})$.

84. Id. § $1229 \mathrm{~b}(\mathrm{~b})(1)$.
} 
Cancellation of Removal is complex to apply because, as is usual in immigration law, there is information external to the main statutory section that dramatically affects its meaning. For example, both continuous residence and continuous physical presence are defined elsewhere in the statute. ${ }^{85}$ To calculate either continuous residence or continuous physical presence, the statute defines that any period artificially ends on the earlier date of either when removal proceedings begin or when the individual commits a listed criminal offense. ${ }^{86}$ The statute further reveals that a break in continuous physical presence occurs if an individual leaves the United States for any one period greater than 90 days or "for any periods in the aggregate exceeding 180 days." individual has actually resided in the United States for seven years but his or her removal proceedings began during his or her sixth year of residence, that individual has not "resided in the United States continuously for 7 years,” according to the statute. Also, an individual who has resided in the United States for 11 years but once visited his or her parents in a foreign country for 91 days has not "been physically present in the United States for a continuous period of not less than 10 years.”

The relief scheme is also complex to apply because it incorporates two difficult immigration law concepts: "good moral character" and "exceptional and extremely unusual hardship." These concepts require a close reading of past adjudications to provide an informed prediction of whether either standard is met. ${ }^{88}$ While the statute does include a list of characteristics that render someone not a person of "good moral character," the list is not exclusive. ${ }^{89}$

Cancellation of Removal is harsh because the statutory requirements set a high bar to achieve relief. The statutory requirements narrow the potential applicability of relief. If an individual cannot meet the many prerequisites, time-based and otherwise, then this form of relief simply is not available. For example, all individuals convicted of aggravated felonies are locked out of Cancellation of Removal. ${ }^{90}$ Also, the statutory requirements are rigid. The statute does not allow room for adjudicators

85. See id. § $1229 \mathrm{~b}(\mathrm{~d})$.

86. See id. § $1229 \mathrm{~b}(\mathrm{~d})(1)$.

87. Id. $\S 1229 \mathrm{~b}(\mathrm{~d})(2)$.

88. See, e.g., Monreal-Aguinaga, 23 I. \& N. Dec. 56, 60-62 (B.I.A. 2001) (describing the "exceptional and extremely unusual hardship" standard as not as high as unconscionable but higher than extreme hardship).

89. See 8 U.S.C. § 1101(f).

90. See id. § $1229 \mathrm{~b}(\mathrm{a})(3)$. 
to consider rehabilitation of the foreign national, nor are other equitable considerations ripe for consideration other than a showing of exceptional and extremely unusual hardship to a narrow group of qualifying relatives. ${ }^{91}$

Compounding the complexity and the harshness is that, even if all of the statutory prerequisites are satisfied, the granting of this form of relief is discretionary. From the foreign national's perspective, immigration judges do not have positive discretion in the sense that the statute does not permit those adjudicators to look at or weigh the totality of circumstances in an individual's case to the individual's potential benefit. The statute does grant immigration judges negative discretion, however, to deny relief even if the foreign national does meet all of the statutory

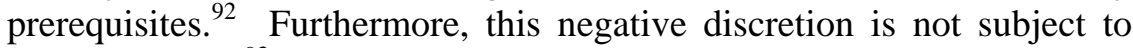
judicial review. ${ }^{93}$

To close out this discussion of the inadmissibility and deportability grounds, it is important to note that the substantive law often provides no statute of limitations on immigration violations. ${ }^{94}$ For example, there is no statute of limitations on removability based on an aggravated felony conviction. ${ }^{95}$ Therefore, the adjudication system is called on to adjudicate cases where the offense that creates removability occurred many years before. ${ }^{96}$

\section{b. Harshness: Other Examples}

Additionally, the dismantled boundaries between civil immigration law, criminal law, and national security law, large increases in

91. See id. § 1229b(b)(1)(D).

92. See id. § 1229b(a); 1229b(b)(1).

93. See id. § 1252(a)(2)(B)(i).

94. Within the criminal-related deportability grounds listed in § 1227(a)(2), only the ground of "crimes of moral turpitude" contains a time limitation. See id. § 1227(a)(2)(A)(i)(I) (establishing a deportability ground triggered by a conviction of a crime of moral turpitude committed within five years after admission).

95. See id. § 1227(a)(2)(A)(iii) (“Any alien who is convicted of an aggravated felony at any time after admission is deportable.”) (emphasis added).

96. For example, a business executive who left his native China at age five found himself in removal proceedings as an adult. Nina Bernstein, For a Pardoned Detainee, Released but Not Told Why, a Lonely, Happy Trip Home, N.Y. TIMES, Mar. 10, 2010, at A27. He had participated in a series of muggings as a teenager but had turned his life around. Id. Many years later, his application for citizenship drew attention to his criminal history. Id. Because his convictions qualified as aggravated felonies, he was not eligible to seek any relief from removal. See id. His only recourse was to petition the governor to pardon him for his earlier crimes. Id. 
enforcement efforts, the absence of proportionality, and the increased use of detention reveal the harshness of substantive immigration law.

Immigration law is harsh because of the dismantled boundaries between civil immigration law, criminal law, and national security law. ${ }^{97}$ Enforcement officials have made clear their position that immigration law is a crime issue and a national security issue. ${ }^{98}$ A characterization of immigration law as criminal law and national security law has resulted in an atmosphere of "zero-tolerance" among immigration enforcement

97. See, e.g., Jennifer M. Chacón, Unsecured Borders: Immigration Restrictions, Crime Control and National Security, 39 CoNN. L. REV. 1827, 1831-32 (2007) (arguing that the blurring of boundaries between immigration control, crime control, and national security have created consequences that neither achieve national security nor accomplish immigration policy goals); Kevin R. Johnson, It's the Economy, Stupid: The Hijacking of the Debate Over Immigration Reform by Monsters, Ghosts, and Goblins (or the War on Drugs, War on Terror, Narcoterrorists, Etc.), 13 CHAP. L. REV. 583, 586-87 (2010) (arguing that immigration is primarily about the migration of people to the United States for jobs rather than drugs or terrorism); Kevin R. Johnson \& Bernard Trujillo, Immigration Reform, National Security After September 11, and the Future of North American Integration, 91 MiNN. L. REV. 1369, 1373 (2007) (arguing that national security concerns have inappropriately dominated the debate over comprehensive immigration reform).

98. Immigration and Customs Enforcement describes its mission as "[t]o promote homeland security and public safety through the criminal and civil enforcement of federal laws governing border control, customs, trade, and immigration.” ICE Overview, U.S. IMMIGRATION AND CUSTOMS ENFORCEMENT, http://www.ice.gov/about/overview/ (last visited Feb. 26, 2011). The Office of Homeland Security Investigations within ICE describes its mission as "[t]o conduct criminal investigations that protect the United States against terrorist and other criminal organizations who threaten our safety and national security." ICE Homeland Security Investigations, U.S. IMMIGRATION AND CUSTOMS ENFORCEMENT, http://www.ice.gov/about/offices/homeland-securityinvestigations/ (last visited Feb. 26, 2011). Further, the Office of Investigations describes its immigration worksite enforcement efforts as playing "an important role in the fight against illegal immigration.” Worksite Enforcement, U.S. IMMIGRATION AND CUSTOMS ENFORCEMENT, http://www.ice.gov/worksite/ (last visited Feb. 26, 2011). The Office of Detention and Removal Management describes itself as "defend[ing] public safety and national security." Detention \& Removal Management, U.S. IMMIGRATION AND CUSTOMS ENFORCEMENT, http://www.ice.gov /about/offices/enforcement-removal-operations/drm/ (last visited Feb. 26, 2011). 
officials. $^{99}$ This colors every removal as a win for the protection of Americans.

This characterization of immigration law dovetails with recent large increases in immigration enforcement efforts. The Department of Homeland Security reported that in fiscal year 2008, it reached its sixth consecutive record high for removals, with almost 359,000 individuals removed. $^{100}$ In 2001, by comparison, the government removed a little more than half of the 2008 total. ${ }^{101}$

Another example of the harshness of immigration law is its lack of proportionality. ${ }^{102}$ As Professor Juliet Stumpf has observed, removal from the United States "is the ubiquitous penalty for any immigration violation." 103 Removal is an "on-off switch," which leaves no room for gradations of punishment dependant on the circumstances of the violation. ${ }^{104}$ Especially as relief from removal has become increasingly out of reach and devoid of proportionality itself, the system metes out one punishment, and one punishment only, no matter the circumstances. ${ }^{105}$ Removal is a harsh punishment, as it forces relocation and limits basic life choices such as living with close family members.

A final example of the harshness of immigration law is that it requires detention in many removal cases. ${ }^{106}$ Immigration and Customs

99. See APPLESEED, supra note 25, at 16-17 (discussing a zero-tolerance mentality among ICE attorneys). On his blog, one immigration lawyer has recounted a client's encounter with immigration officials that illustrates this zero-tolerance attitude. Carl Shusterman, Freeing a Family from CBP Custody: A Lawyer's Perspective, NATION OF IMMIGRANTs (Feb. 14, 2010, 10:48 AM), http://shusterman.typepad.com/nation-of-immigrants/2010/02/an-illegal-checkpoint-stop-a-lawyersperspective.html. His client, a registered nurse, had legal permission to be in the United States. Id. She was stopped, with her family, at an interior checkpoint in California. Id. Through a series of misunderstandings of some complicated immigration law concepts, immigration officials took the erroneous position that the nurse and her family should be detained. Id. The lawyer tried to explain the mistake to a government supervisor. Id. The supervisor told the lawyer that while the lawyer may be correct about the law, "we have to do what we have to do, and we will let the Immigration Judge decide what to do with your clients." Id. The attorney eventually did secure the release of the family without a hearing before an immigration judge, but the story is emblematic of the zerotolerance attitude and how that attitude can create more immigration litigation. Id.

100. DHS OFFICE OF IMMigRATION STATISTICS, IMMigRATION ENFORCEMENT ACTIONS: 2008, at 1 (2009), available at http://www.dhs.gov/xlibrary/assets/statistics/publications/enforcement _ar_08.pdf.

101. Id. at 4 tbl.2.

102. See Juliet Stumpf, Fitting Punishment, 66 WASH. \& LEE L. REV. 1683, 1684 (2009).

103. Id.

104. Id. at 1690-91. The on-off switch may be an effort to interject simplicity into the law, but the simplicity is misplaced. In the case of proportionality, simplicity leads to harshness.

105. See id. at 1693-1704.

106. See Peter L. Markowitz, Barriers to Representation for Detained Immigrants Facing Deportation: Varick Street Detention Facility, a Case Study, 78 FoRDHAM L. REV. 541, 542 (2009). 
Enforcement (ICE) is setting detention records. ${ }^{107}$ In fiscal year 2008, ICE detained 378,582 individuals, which was a twenty-two percent increase from the year before. ${ }^{108}$ Immigration detention is almost indiscernible from criminal detention, but the immigration violation is a civil offense. ${ }^{109}$ The detention can take place in a prison that also houses criminal offenders. ${ }^{110}$ Even facilities reserved exclusively for immigration detainees have notorious reputations. ${ }^{111}$

\section{c. Opacity}

Immigration law is opaque because it is difficult for even seasoned practitioners to predict outcomes. The penalty choice is clear-either removal or no removal-but the path that leads to that end point is notoriously difficult to navigate. While no area of law is completely transparent, immigration law is detrimentally elusive. ${ }^{112}$ There are three main causes of this feature. One is the complexity of the law itself. The second is the tremendous role of discretion in applying substantive immigration law. ${ }^{113}$ The third is the prolific use of nonregulatory administrative tools, such as individual adjudication decisions or policy memoranda, to govern how the agency should interpret the substantive law. ${ }^{114}$

107. DHS OFFICE OF IMMIGRATION STATISTICS, supra note 100 , at 3.

108. Id.

109. See generally Stephen H. Legomsky, The New Path of Immigration Law: Asymmetric Incorporation of Criminal Justice Norms, 64 WASH. \& LEE L. REV. 469, 489-94 (2007).

110. See Nina Bernstein, Sick Detainees Complicate Plans to Close Immigration Jail, N.Y. TIMES, Feb. 24, 2010, at A18 (noting that immigration authorities rent cells in county jails).

111. See, e.g., id. (describing the overcrowded and poor conditions of the Varick Facility in New York). See generally Markowitz, supra note 106, at 552-54 (providing an overview of the Varick Facility).

112. Professor Colin Diver analyzed the precision of the adjustment of status regulations and found those regulations to be flawed. Colin S. Diver, The Optimal Precision of Administrative Rules, 93 YALE L.J. 65, 80 (1983). Professor Diver described the standardless discretion involved in the adjustment decision and argued that the transaction costs of such standardless discretion are substantial. Id. at 93-95.

113. Professors Adam Cox and Cristina Rodríguez have argued that the executive branch's discretion consists of even more than that expressly delegated by Congress. Adam B. Cox \& Cristina M. Rodríguez, The President and Immigration Law, 119 YALE L.J. 458, 475 (2009). The executive branch also holds a great deal of de facto delegated power through its prosecutorial discretion function. See id. at 464. The vastness of the prosecutorial discretion function contributes to the opacity of immigration law, as it is unclear to a large population of individuals if they will even be subject to removal proceedings.

114. See Neuman, supra note 60, at 623-24 ("Discretion delegated by statute can also be exercised through reasonably designed regulations that identify categories of cases in which relief is warranted or unwarranted. It is well known, however, that the immigration authorities have been 
The aggravated felony deportability ground is an example of how the complexity of the law makes it hard to predict outcomes. Justice Alito has discussed how it is difficult for attorneys to predict whether a particular offense is an aggravated felony. ${ }^{115}$ It is a difficult task, and even deciphering the practice of one court of appeals can be intense and unsatisfying. Similarly, the study of the Cancellation of Removal relief provision reveals several complex points where outcomes become difficult to predict, such as whether someone is a person of good moral character or whether there is exceptional and extremely unusual hardship. ${ }^{116}$

The drug inadmissibility waiver also reveals how immigration law is opaque. The waiver is opaque because, just as with Cancellation of Removal, the decision to grant the waiver, no matter if the applicant jumps through every statutory hoop, is left to the undefined discretion of the executive branch. ${ }^{117}$ There is no direction to the executive branch on how to exercise this discretion. Additionally, the section eliminates judicial review of the decision whether to grant the waiver. ${ }^{118}$ To predict whether an individual will be granted a waiver, attorneys must rely on experience or networked advice. ${ }^{119}$ There is little statutory or regulatory guidance. ${ }^{120}$ This makes immigration law especially opaque to anyone new to immigration law, including foreign nationals.

The waiver is also opaque in that additional administrative guidance exists mainly through opinions produced in individual adjudications. For example, while the waiver is directed toward those applying for admission as a lawful permanent resident, the statute instructs that if the

extremely reluctant to narrow their discretion to deny relief by regulation.”).

115. See supra note 62 .

116. See supra notes 85-96 and accompanying text.

117. See, e.g., Goldeshtein, 20 I. \& N. Dec. 382, 387-88 (B.I.A. 1991) (affirming decision of an immigration judge to deny a waiver despite that the applicant may have proved extreme hardship), rev'd on other grounds, Goldeshtein v. INS, 8 F.3d 645 (9th Cir. 1993); see also supra note 92 and accompanying text.

118. See supra note 68 and accompanying text.

119. See, e.g., AM. ImMigration LaW Found., § 212(h) Eligibility: Case LAW AND Potential ARGUMENTS (2008), available at http://www.ailf.org/lac/pa/212elig.pdf (practice advisory for attorneys addressing § 212(h) statutory eligibility).

120. By regulation, the executive branch has indicated that it usually will not grant such waivers where the underlying violation involved a violent or dangerous crime. 8 C.F.R. § 1212.7(d) (2010). That regulation provides some guidance but does not address violations that do not involve a violent or dangerous crime. Also, the regulation is vague even with respect to violent or dangerous crimes. The regulation states: "The [executive], in general, will not favorably exercise discretion under section 212(h)(2) of the Act (8 U.S.C. 1182(h)(2)) ... in cases involving violent or dangerous crimes, except in extraordinary circumstances. ... Moreover, depending on the gravity of the alien's underlying criminal offense, a showing of extraordinary circumstances might still be insufficient ....” Id. (emphasis added). 
applicant for the waiver is someone who was previously admitted in that status, and lost it, certain restrictions apply. ${ }^{121}$ What about the waiver applicant who has never held lawful permanent resident status? Do those restrictions apply to him or her as well? If not, that would put someone who has never been a lawful permanent resident on stronger footing than someone who previously held that close connection to the United States. The answer to the question comes not from a regulation, but rather from an individual adjudication. ${ }^{122}$ Also, the waiver statute sets an "extreme hardship" standard. ${ }^{123}$ The meaning of that standard is found through synthesizing the results of individual adjudications; the standard is intensely case-specific. ${ }^{124}$

d. The Links Between the Adjudication System and the Harshness, Complexity, and Opacity of Immigration Law

The harshness, complexity, and opacity of immigration law impact the adjudication system and must be considered when reforming the system. The harshness and complexity create the need for more adjudication. ${ }^{125}$ The harshness, complexity, and opacity together contribute to immigration law's lack-of-representation problem and to its esteem problem.

121. See supra notes $72-73$ and accompanying text.

122. See Michel, 21 I. \& N. Dec. 1101, 1104-05 (B.I.A. 1998) (holding that an individual who did not previously hold lawful permanent resident status is eligible for a 212(h) waiver, despite that the individual fell under a waiver exclusion applicable to those with previous lawful permanent resident status).

123. See supra note 70 and accompanying text.

124. See, e.g., Cervantes-Gonzalez, 22 I. \& N. Dec. 560, 565-68 (B.I.A. 1999) (addressing the extreme hardship standard).

125. Others have more generally examined how the nature of a substantive rule affects adjudication under that rule. For example, Professor Colin Diver has argued that an opaque administrative rule increases the cost of applying that rule and that transparent rules allow for more predictability, which in turn lessens the amount of litigation. See Diver, supra note 112, at 73-74. In immigration law, concern about transparency must be balanced against other factors that also influence the quality of immigration adjudication. For example, transparent rules that do not incorporate space to consider proportionality or rehabilitation will still leave foreign nationals with a strong incentive to access adjudication. 


\section{i. Caseloads}

Immigration judge caseloads continue to climb to record levels. ${ }^{126}$ In fiscal year 2009, approximately 230 immigration judges completed 290,233 proceedings. ${ }^{127}$ Proceedings are more intensive hearings and do not include bond hearings and other motions-thus this number does not represent total workload. ${ }^{128}$ Proceedings alone average over 1200 per year per judge. Despite this frenetic pace, a backlog of cases continues to build. In September 2010, 261,083 cases were pending before the immigration courts. ${ }^{129}$ This backlog is forty percent higher than the backlog two years before. ${ }^{130}$ The average wait time for a case before an immigration judge is 456 days. ${ }^{131}$ Despite these daunting and growing caseloads, immigration judge hiring has been slow, and immigration judges on the bench lack adequate training and other in-house resources, like law clerks. ${ }^{132}$

The harshness and complexity of the substantive law creates the need for more adjudication. The substantive law accomplishes this in three main ways. First, the substantive law drives the docket. The inadmissibility and deportability grounds are now extremely broad and unforgiving. ${ }^{133}$ As the grounds widen, more individuals will be removable from the United States. In turn, that signals a need for more adjudication as each charge of removability carries the possibility of a challenge to the charge through adjudication. ${ }^{134}$ Any reform to the system must realistically consider the load placed on the system by the substantive law. Also, reform should consider the complexity of the adjudication once it begins. What relief from removal is available is

126. See Transactional Records Access Clearing House, As FY 2010 Ends, Immigration Case Backlog Still Growing (Oct. 21, 2010), http://trac.syr.edu/immigration/reports/242/.

127. Transactional Records Access Clearinghouse, Number of Immigration Judges, 1998-2009, http://trac.syr.edu/immigration/reports/225/include/payroll.html (last visited Feb. 26, 2011); ExEC. OfFICE FOR IMMigration REVIEW, FY 2009 STATISTICAL YEAR BOOK B7 (2010), available at http://www.justice.gov/eoir/statspub/fy09syb.pdf.

128. See EXEC. OfFICE FOR IMMIGRATION REVIEW, supra note 127, at B7.

129. Transactional Records Access Clearinghouse, supra note 126.

130. Id.

131. Id.

132. See Family, supra note 4, at 600-01; Transactional Records Access Clearinghouse, supra note 127.

133. See supra Part III.B.1.a.

134. See Edward R. Grant, Laws of Intended Consequences: IIRIRA and Other Unsung Contributors to the Current State of Immigration Litigation, 55 CATH. U. L. REV. 923, 963 (2006) (acknowledging that the work of immigration adjudicators is fed by substantive policy choices). 
buried in a thicket that requires a well-seasoned lawyer to cut through. The complexity of the law leads to more complicated adjudications.

Second, the way the substantive law is enforced also drives the docket. Zero-tolerance policies and large increases in enforcement create the need for more adjudication. The harsh zero-tolerance attitude, and its corresponding lack of prosecutorial discretion, pushes more cases into the adjudication system. ${ }^{135}$ Once these cases enter the system, a natural inclination is to attempt to access relief from removal. To access relief, adjudication is necessary.

Third, the harsh lack of proportionality may increase the need for adjudication. Because only extreme outcomes to a removal hearing are available (either removal or no removal), the stakes are high enough to motivate adjudication. If a scheme of more proportional punishment existed for certain classes of foreign nationals - such as fines-those charged with those violations might be less inclined to challenge the charge through adjudication. ${ }^{136}$ For example, a new relief scheme could be created where long-term legal permanent residents convicted of minor crimes could be subjected to a civil fine as punishment for violating the immigration laws due to the conviction, rather than being subject to removal. If a long-term resident knows that the potential ultimate penalty is a fine, and not removal, that individual may be more inclined to pay the fine than to challenge the charge through adjudication.

The President of the National Association of Immigration Judges has described immigration court hearings as "“like holding death penalty cases in traffic court.",137 This description encapsulates the complicated relationship between the substantive law and the adjudication system illustrated here. The broad nature of the substantive law, and the way that it is enforced, creates the need for a high volume adjudication system. But the substantive law is so complex and so harsh that immigration judges are called on to apply law that cries out for the resources of a low volume system.

\footnotetext{
135. An effort to exercise prosecutorial discretion and remove some cases from the system may be underway. See Susan Carroll, Feds Moving to Dismiss Some Deportation Cases, Hous. Chron., Aug. 25, 2010, at A1. See generally Shoba Sivaprasad Wadhia, The Role of Prosecutorial Discretion in Immigration Law, 9 CONN. PUB. INT. L.J. 243 (2010) (discussing immigration prosecutorial discretion).

136. Professor Stumpf has more fully discussed potential alternative penalties. Stumpf, supra note 102, at 1737-40. This Article is focused on how the harshness of the potential penalty may affect adjudication.

137. Julia Preston, Lawyers Back Creating New Immigration Courts, N.Y. TimEs, Feb. 9, 2010, at A14.
} 
If the penalty for speeding became automatic loss of the driver's license (or worse), then surely more individuals would appear in traffic court to contest their guilt. Because the penalty is usually just a fine, the incentive to appear in traffic court is lower than if the penalty were harsher. An increase in the harshness of the substantive law would cause an increase in volume in traffic court, which would, in turn, challenge the ability of the traffic court to function. Similarly, if the inquiry to determine whether someone should lose their license under the new regime became as complex as immigration law, the increased time necessary to adjudicate each case would put greater pressure on the traffic court's ability to manage its caseload.

A study of high volume administrative systems described the following characteristics of a high volume system: "a need for short hearing time (typically one hour or less for most high-volume categories), quick decisional response, high judge productivity (30 or more written decisions per month per judge) and docketing/scheduling practices capable of efficiently handling...endless lines of short causes." "138 These characteristics are simply a mismatch to the adjudication needs created by substantive immigration law.

Thus, the effect of the substantive law on the volume of cases is a key factor in designing a complementary adjudication system, including the design of immigration adjudication reform. A solution may be to increase the capacity and resources of the court to allow it to handle the docket. Another possibility is to reform the substantive law, making it less harsh and less complex so that the substantive law matches the needs of a high volume system. Decisional independence alone, however, will not address the caseload crisis.

\section{ii. Representation}

Compounding caseload troubles is a lack of quality legal representation for foreign nationals in immigration court. In fiscal year 2009, sixty-one percent of respondents in immigration court did not have attorney representation. ${ }^{139}$ Of those detained during their civil immigration hearing, less than twenty percent appeared with an attorney. ${ }^{140}$ There are also serious concerns about the quality of

138. Daniel L. Skoler, The Many Faces of High-Volume Administrative Adjudication: Structure, Organization and Management, 16 J. NAT'L Ass'N ADMIN. L. JUDGES 43, 47 (1996).

139. EXEC. OFFICE FOR IMMIGRATION REVIEW, supra note 127, at G1.

140. Nina SiUlC Et AL., Vera InStitute OF Justice, ImProving EFFiCienCy AND Promoting 
representation provided by some attorneys and about the unauthorized practice of immigration law. ${ }^{141}$ The substantive law not only affects caseloads but also impacts immigration adjudication because it contributes to the extreme lack of lawyers in the system. ${ }^{142}$ The complexity, harshness, and opacity of immigration law contribute to and illustrate the significance of this extreme lack of representation.

Why is it significant that so many foreign nationals appear in immigration court without representation? The complexity, harshness, and opacity of immigration law dictate that individuals appearing pro se are at a huge disadvantage. ${ }^{143}$ The complicated patchwork of difficult statutes and nonregulatory adjudicatory tools effectively cuts off foreign nationals from participating in their own removal proceedings. ${ }^{144}$ The complicated waiver provision and the Cancellation of Removal provisions described above are just two examples of the complexity that lies behind the deceptively simple concept of relief from removal. ${ }^{145}$ If a noncitizen wants to argue that he or she is entitled to relief from removal, the argument must be made in conformity with statutes that challenge law students (and even lawyers and law professors). Without guidance from an attorney, individuals in removal proceedings are at the mercy of immigration judges and immigration prosecutors to identify and evaluate any possible relief from removal. ${ }^{146}$ The aggravated felony removal ground is so intricate that the Supreme Court has granted certiorari to

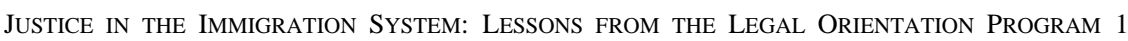
(2008), available at http://www.vera.org/download?file=1780/LOP\%2BEvaluation_May2008_ final.pdf.

141. Family, supra note 4, at 604 .

142. The ABA Study recognized the lack of representation as a challenge to the functioning of the adjudication system. ABA STUDY, supra note 11, at ES-39 to -42. It does not, however, recognize how the substantive law itself contributes to the lack of representation problem.

143. See Jennifer L. Colyer et al., The Representational and Counseling Needs of the Immigrant Poor, 78 FORDHAM L. REV. 461, 463 (2009) (describing the vulnerabilities of those subject to immigration court proceedings, including a lack of "money, substantial education, or language skills”); Johnson, supra note 61, at 1637-38 (discussing the incomprehensibility of immigration law to laypeople); Andrew I. Schoenholtz \& Hamutal Bernstein, Improving Immigration Adjudications Through Competent Counsel, 21 Geo. J. Legal Ethics 55, 58 (2008) ("Evidence shows that unrepresented cases are less likely to be successful.”).

144. According to one study, $39.2 \%$ of immigration detainees had possible meritorious claims for relief, but almost all of the detainees were unfamiliar with the relief provisions. CITY BAR Justice Ctr., NYC Know Your Rights Project: An InNovative Pro Bono Response to the LACK OF COUNSEL FOR INDIGENT IMMIGRANT DETAINEES 2, 14 (2009).

145. See supra Part III.B.1.a.

146. See Colyer et al., supra note 143, at 464 ("The government will be on one side with its awesome power, extensive institutional experience, and sophisticated understanding of the law. An immigration judge will be presiding, who might be sympathetic to the immigrant's story, but who would benefit from an adversarial presentation. And the immigrant will often be standing all alone ....”). 
hear many complex arguments surrounding its application. ${ }^{147}$ Given the zero-tolerance attitude of immigration enforcement officials and the caseload management pressures placed on immigration judges, it is highly questionable whether the interests of the unrepresented noncitizen are accounted for in immigration court. To truly fight an immigration charge, the noncitizen needs a lawyer.

To adjudicate a removal case effectively, the system also needs lawyers. Because of the complexity of immigration law, pro se representation makes the job of the immigration judge even more difficult. Without an attorney, if the immigration judge is concerned about the lack of representation, the immigration judge will need to perform the role of the missing lawyer. The immigration judge will need to explain the complexities of immigration law to the individual and will need to conduct a detailed factual inquiry to determine eligibility for relief.

The complexity and opacity of immigration law discourage attorney representation because those characteristics make it difficult to only occasionally practice immigration law. ${ }^{148}$ Because of the complexity of immigration law ${ }^{149}$ and because the law itself simply can be so difficult to locate, ${ }^{150}$ the substantive law creates a high barrier to entry. This discourages attorneys in other practice areas to take on immigration cases, whether paid or pro bono. Thus, the substantive law itself is a barrier to the provision of pro bono services and keeps the pool of available attorneys small.

The harshness of immigration law contributes to the representation problem because it builds on a negative stereotype of foreign nationals in removal proceedings and because the increased use of detention deters

147. See, e.g., Carachuri-Rosendo v. Holder, 130 S. Ct. 2577 (2010); Gonzales v. DuenasAlvarez, 549 U.S. 183 (2007); Lopez v. Gonzales, 549 U.S. 47 (2006); Leocal v. Ashcroft, 543 U.S. 1 (2004).

148. There are other causes that discourage attorney representation. See Markowitz, supra note 106, at 546-51, 556-63.

149. A subcommittee of the Study Group on Immigration Representation questioned lawyers in New York City about their experiences in immigration cases. Colyer et al., supra note 143, at 46970. The subcommittee reported that "[i]ssues heard over and over were lack of internal expertise in immigration law at the firm.” Id. at 471. The respondents also cited the difficulties in training attorneys to take on immigration cases as a barrier to representation. Id. Whether an attorney is willing to become competent in immigration law is a factor in determining the future of immigration representation. $I d$. at 476.

150. Accessibility would improve if the immigration agencies issued more regulations, rather than relying on individual adjudications or subregulatory guidance. For example, Professor Daniel Kanstroom has called for the issuance of more regulations to govern exercises of discretion. Daniel Kanstroom, Surrounding the Hole in the Doughnut: Discretion and Deference in U.S. Immigration Law, 71 TUL. L. REV. 703, 804-06 (1997). 
representation. The government's efforts to brand the removal process as a tool to protect Americans from crime and national security threats may cause some attorneys to think twice before engaging in representation. Furthermore, the increased use of detention, a harsh aspect of the substantive law, can serve as a deterrent to representation. $^{151}$ Detention makes representation more difficult, especially because the government is well known to execute sudden and inexplicable transfers of immigrant detainees. ${ }^{152}$ A lawyer cannot be sure that his or her client will be in the same facility tomorrow. In fact, the government may transfer the client across the country, and the lawyer may need to spend significant resources merely to locate the client. ${ }^{153}$ Thus, the harshness of the substantive law demands an incredibly high level of stamina and requires an attorney willing to take on an unpopular cause.

The lack of attorney representation leaves foreign nationals at a huge disadvantage, but it also hinders the ability of the system to progress. Creating more independent adjudicators would not resolve all of the issues surrounding why the representation rate is so low. For example, creating more independent adjudicators would not make it any easier for attorneys only occasionally to practice immigration law.

\section{iii. Esteem}

Immigration law's esteem problem also contributes to the existence of only a small pool of available attorneys who possess the necessary expertise, sophistication, and stamina. Immigration law has an esteem problem because it is sometimes perceived as an outlier among, and inferior to, other areas of law, ${ }^{154}$ including administrative law. ${ }^{155}$ The

151. See Colyer et al., supra note 143, at 470 (describing a study in which some firms indicated they were deterred from representing detainees because of the risk of transfer); Markowitz, supra note 106, at 556-60 (indicating the same conclusion based on interviews conducted by the author).

152. Markowitz, supra note 106, at 556-57.

153. Id. at 557.

154. See Leslie C. Levin, Guardians at the Gate: The Backgrounds, Career Paths, and Professional Development of Private US Immigration Lawyers, 34 LAW \& SoC. INQUIRY 399, 400 (2009). In fact, even among immigration lawyers, representation of individuals in removal hearings is perceived as an unprestigious type of immigration law practice. See id. at 412-14.

155. See Kevin R. Johnson, Hurricane Katrina: Lessons About Immigrants in the Administrative State, 45 Hous. L. REV. 11, 18 (2008) ("[I]mmigration law-although administered and enforced through a complex and powerful administrative bureaucracy-is considered to be a specialty area outside the mainstream of administrative law or U.S. law generally.”); Margaret H. Taylor, Promoting Legal Representation for Detained Aliens: Litigation and Administrative Reform, 29 CONN. L. REV. 1647, 1653-54 (1997) (addressing an impression "that immigration law is too 
immigration agencies themselves, including administrative adjudicators, are often the subject of criticism. ${ }^{156}$ The complexity of immigration law is notorious. ${ }^{157}$ Even the quality of some immigration lawyers is questioned, and the unauthorized practice of immigration law is prevalent. ${ }^{158}$ Compounding the esteem problem is that immigration law is an isolated area of law where usual legal conventions do not apply. ${ }^{159}$

While there are many excellent immigration law practitioners who find their work extremely rewarding, the lack of representation in immigration court may also be due to a negative mystique attached to immigration law. Due to its isolated status, its complexity, and the struggling reputations of the immigration agencies and attorneys, immigration law can seem to be a fortress. It is filled with laws and procedures so complex, so harsh, so technical, and so exasperating that those who do enter the realm tend to stick together. ${ }^{160}$ Conquering the complexity and harshness takes so much time and energy that connections to the outside legal world are too few and far between. This lack of connections only compounds the negative mystique of immigration law.

specialized to be a useful field of inquiry for those who are not tutored in its complexities"). In some ways, the outlier status of immigration law is similar to the status of tax law. For a discussion of the isolation of tax law, see Paul L. Caron, Tax Myopia, or Mamas Don't Let Your Babies Grow Up to Be Tax Lawyers, 13 VA. TAX REV. 517 (1994).

156. See, e.g., Benslimane v. Gonzales, 430 F.3d 828, 829-30 (7th Cir. 2005) (“This tension between judicial and administrative adjudicators is not due to judicial hostility to the nation's immigration policies or to a misconception of the proper standard of judicial review of administrative decisions. It is due to the fact that the adjudication of these cases at the administrative level has fallen below the minimum standards of legal justice."); see also MiLTON D. MORRIS, IMMIGRATION-THE BELEAGUERED BUREAUCRACY 87-133 (1985) (examining common reasons for the criticism of immigration agencies); Kevin R. Johnson, Los Olvidados: Images of the Immigrant, Political Power of Noncitizens, and Immigration Law and Enforcement, 1993 BYU L. REV. 1139, 1205-09 (describing areas in which immigration agencies have faced criticism); David A. Martin, Reforming Asylum Adjudication: On Navigating the Coast of Bohemia, 138 U. PA. L. REV. 1247, 1267 n.59 (1990) (noting the low esteem of immigration agencies).

157. See, e.g., Drax v. Reno, 338 F.3d 98, 99 (2d Cir. 2003) (“This case vividly illustrates the labyrinthine character of modern immigration law-a maze of hyper-technical statutes and regulations that engender waste, delay, and confusion for the Government and petitioners alike.”).

158. See Markowitz, supra note 106, at 543-44, 562; Careen Shannon, Regulating Immigration Legal Service Providers: Inadequate Representation and Notario Fraud, 78 FORDHAM L. REV. 577, 584-86 (2009).

159. See Peter H. Schuck, The Transformation of Immigration Law, 84 COLUM. L. REV. 1, 1 (1984) ("Immigration has long been a maverick, a wild card, in our public law. Probably no other area of American law has been so radically insulated and divergent from those fundamental norms of constitutional right, administrative procedure, and judicial role that animate the rest of our legal system.”); see also Stacy Caplow, ReNorming Immigration Court, 13 NEXUS 85, 94-95 (2008) (discussing the lack of rules of evidence in immigration adjudication); Johnson, supra note 61, at 1622 (stating that "U.S. immigration laws deviate dramatically from other areas of American law").

160. For more on the community of immigration lawyers, see Levin, supra note 154, at 429-32. 
This esteem problem has repercussions both for quality representation and for high-class administrative judging. The esteem problem can deter a quality lawyer from practicing immigration law and thus is another contributor to the lack-of-representation problem. Practicing immigration law requires an intense fighting spirit and an understanding that both the substantive law and the attitude of enforcement officers are heavily stacked against the client, and that there is little to no room for compromise. Also, the high level of unreviewable discretion delegated to executive immigration officials makes it difficult for an attorney to predict outcomes to clients. ${ }^{161}$ Additionally, the reputation of the immigration law bar as a whole risks damage from shoddy representation by some lawyers and by those engaged in the unauthorized practice of law. ${ }^{162}$ Finally, the characterization of immigration law as criminal and national security law clouds the reputation of the field. It can be discouraging to represent someone who the lawyer knows has a minimal chance of success or to lead a client through a dysfunctional, unpredictable, and unpopular system. The reputation of the system is poor, and some attorneys may not want to associate themselves with such a system.

The esteem problem also hinders administrative judging because it reflects a diminished stature for administrative immigration adjudicators. The harshness of the substantive law often does not allow adjudicators to judge. Limited relief provisions and the lack of proportionality all tie the hands of immigration adjudicators. The nature of immigration law is stifling the deliberative aspect of being an adjudicator. While there is some room for deliberation, such as deciding whether the "exceptional and extremely unusual hardship" standard is met, the parameters of that discretion are very narrow. Also, while negative discretion is built into the system, such as when an immigration judge has discretion to deny relief even if all of the statutory parameters are met, this discretion is restrained because it is focused in one direction-denial. Thus, the law sends a signal that an adjudicator is only needed to robotically apply laws

161. One immigration attorney noted that immigration agency policies are "as reliable and ephemeral as the inducements of a carnival barker." Angelo Paparelli, An Immigration Signature Story Yet Untold: How Far a Modern Quill Doth Come Too Short, ANgelo PaPARELli on DYSFUNCTIONAL GOVERNMENT (February 5, 2010, 12:49 AM), http://blogs.ilw.com/ angelopaparelli/2010/02/signature.html (describing the changing agency policy over who can sign an immigration form). Professor Regina Germain has highlighted that immigration adjudication has no procedural rules. Regina Germain, Putting the "Form" in Immigration Court Reform, 84 DENV. U. L. REV. 1145, 1145 (2007).

162. See Markowitz, supra note 106, at 543-44, 562. 
that leave little room for judgment. ${ }^{163}$ The nature of the position may affect the applicant pool.

The creation of more independent immigration adjudicators could positively affect immigration law's esteem problem. The job security and prestige of an Article I position, for example, may attract higher quality adjudicators. Those adjudicators and the attorneys who appear before them, however, would still need to apply the same deflating substantive law.

This discussion reveals that the state of substantive immigration law is linked to the health of the adjudication system designed to apply it. The harshness and complexity of the substantive law lead to the need for more adjudication. The harshness, complexity, and opacity together contribute to immigration law's representation and esteem problems. While decisional independence is important, that independence will not be as meaningful if the newly independent adjudicators still face crushing caseloads, if still not enough lawyers participate in the system, and if the esteem problem continues to frustrate quality adjudication.

\section{The Conflicting Signals of Immigration Adjudication}

What is the purpose of immigration adjudication? Resolution of this question would improve immigration adjudication. Quality adjudication depends on a clear sense of purpose, and the participants in the systemas well as the public - should understand the mission of the adjudication system.

The system currently sends conflicting signals about its purpose. In three main ways, the functioning of the system undercuts its appearance as a civil adjudicatory system staffed by "judges" who will review agency activities. The first conflicting signal relates to decisional independence. Through its history, the system has become more formal, and separation of functions has increased, but as described above, the system still lacks decisional independence. A second set of conflicting signals is found through contrasting the increase in separation of

163. One criticism of specialized courts is that their narrow jurisdiction increases "the danger of making the job repetitive and unattractive or of low prestige.” David P. Currie \& Frank I. Goodman, Judicial Review of Federal Administrative Action: Quest for the Optimum Forum, 75 CoLUM. L. REV. 1, 73 (1975). The role of the immigration judge is plagued by even more than narrow jurisdiction because the immigration judge's authority within that narrow jurisdiction is constrained. 
functions against the system's limited review power over many discretionary actions. A third set of conflicting signals is found by examining the nature and tenor of a removal hearing. By definition, a removal hearing is just another type of civil administrative adjudication. In reality, the system operates with the attitude of a criminal trial.

Immigration adjudication has moved toward greater separation of functions over time. ${ }^{164}$ For example, adjudicators no longer also represent the government in proceedings or work for the same agency as immigration enforcement. ${ }^{165}$ This evolution tells a story of a move toward a more formal adjudication system that depends on a professional corps of adjudicators who focus on adjudication. But these adjudicators are still under the thumb of the nation's top law enforcement official and lack decisional independence. Placing these adjudicators under the control and supervision of the Attorney General conflicts with the concerns that pushed the system towards greater separation of functions. Creating new adjudication positions with decisional independence would alleviate this conflicting signal.

But the lack of decisional independence contrasted against a desire for separation of functions is not the only conflicting signal. The increased separation of functions also stands in contrast to a system where discretion reigns supreme. ${ }^{166}$ Professor Gerald Neuman uncovered one example of the strong role of discretion by arguing that efforts to move cases faster through the Board of Immigration Appeals resulted in the Board's ineffective supervision of immigration judges' exercises of discretion. ${ }^{167}$ The Board's actual level of oversight, then, is less than it may appear. The same reasoning applies to unreviewable exercises of discretion vested in nonadjudicatory executive officers. ${ }^{168}$ Because the substantive law delegates unreviewable discretion to nonadjudicatory executive officials, the substantive law dictates that immigration adjudicators are powerless over those decisions. Thus, the system is sometimes programmed to effectuate little to no actual review.

164. See Jill E. Family, Conflicting Signals: Understanding US Immigration Reform Through the Evolution of US Immigration Law, 40 REVISTA CATALANA DE DRET PÚBLIC 145, 155-58 (2010).

165. Id.

166. See Neuman, supra note 60, at 631-33.

167. See id. at 633 (arguing that the streamlining reforms weakened the Board's ability "to promote consistency in the decentralized exercise of authority by Immigration Judges of widely varying temperaments and tastes").

168. See, e.g., S-K-, 23 I. \& N. Dec. 936, 941, 942 n.7 (B.I.A. 2006) (discussing how Congress delegated power to grant a waiver of the terrorism inadmissibility grounds to the Attorney General, the Secretary of State, and the Secretary of Homeland Security but not to immigration judges or the Board). 
Injecting decisional independence into the system would do little to address this conflicting signal. Decisional independence only carries as far as the independent adjudicator's jurisdiction. If the adjudicator lacks jurisdiction, either formally or effectively, then the adjudicator's independence becomes less relevant. An adjudicator with decisional independence is a necessary goal, but the breadth of that independent adjudicator's power is important. If the substantive law does not allow this adjudicator to review crucial decisions, then the decisional independence afforded may not be satisfying.

Another set of conflicting signals comes from the criminal-like tenor of immigration adjudication. ${ }^{169}$ Removal proceedings are civil agency adjudications in name. ${ }^{170}$ In practice, however, the tone of a removal proceeding resembles a criminal trial, where the noncitizen is on "trial" and the Department of Homeland Security attorney "prosecutes." A removal action begins with the issuance of a Notice to Appear, which lists the government's "charges" against the noncitizen. ${ }^{171}$ During the hearing before the immigration judge, the foreign national responds to the charges and also applies for relief from removal, if available. ${ }^{172} \mathrm{~A}$ noncitizen, for example, may admit to the immigration violation charge but seek asylum (refugee) status as relief from the immigration violation. The hearing would then focus on the noncitizen's eligibility for asylum.

To determine eligibility, the foreign national will most likely present testimony and evidence in support of his or her application for asylum. To show that he or she is eligible for asylum, the noncitizen must show past "persecution or a well-founded fear of future persecution on account of race, religion, nationality, membership in a particular social group or political opinion." ${ }^{173}$ Because most individuals do not flee their home country with tangible evidence of persecution, most of these cases turn on questions of credibility - whether the immigration judge believes the testimony of the noncitizen as to events that occurred in the home country. ${ }^{174}$ The government attorney often will attempt to rebut the testimony and evidence, mainly through a tough cross-examination

169. Despite the increasing criminalization of immigration law, the adjudication system remains civil and lacks the procedural protections of a criminal system. See Legomsky, supra note 109, at 472. This discussion focuses on the tone of the civil hearing.

170. See id. at 511-12.

171. 8 U.S.C. § 1229(a)(1) (2006).

172. See id. § 1229a.

173. Id. § 1101(a)(42)(A).

174. See Armen H. Merjian, A Guinean Refugee's Odyssey: In Re Jarno, The Biggest Asylum Case in U.S. History and What It Tells Us About Our Broken System, 23 GEO. IMMIGR. L.J. 649, 666, 685-87 (2009). 
aimed at destroying the noncitizen's credibility. ${ }^{175}$ The immigration judge is directed to adopt an inquisitorial role, and will interject with questions during the hearing. ${ }^{176}$ The search for inconsistency may not account for language, cultural, or psychological factors. ${ }^{177}$

Thus, the government's objective can seem to be to defeat the application for asylum through any method, without considering the merits of the case. ${ }^{178}$ Recently, a court of appeals reminded the government that its role is to "seek justice rather than victory," and was "distressed" that the government failed to live up to that duty in the case before it. ${ }^{179}$ The government's goal is to "convict," rather than to find cases where relief is appropriate or even a more neutral approach to simply enforce the law. ${ }^{180}$ The perception is that the government views as a victory a denial of relief accompanied by a removal order; in other words, a "guilty" verdict. ${ }^{181}$ The opposite result-essentially, "not guilty"-necessarily would be categorized as a loss. ${ }^{182}$ Thus, despite that

175. See Won Kidane, Revisiting the Rules of Procedure and Evidence Applicable in Adversarial Administrative Deportation Proceedings: Lessons from the Department of Labor Rules of Evidence, 57 CATH. U. L. REV. 93, 135-41 (2007).

176. See 8 U.S.C. § 1229a(b)(1); OfFICE OF THE CHIEF IMMigRATION JUdGe, IMMigRATION COURT PRACTICE MANUAL $\S 4.16(\mathrm{e})$, at 77 (2009), available at http://www.justice.gov/eoir/vll/ OCIJPracManual/Practice\%20Manual\%20Final_compressedPDF.pdf.

177. See Stuart L. Lustig, Symptoms of Trauma Among Political Asylum Applicants: Don't Be Fooled, 31 HASTINGS INT'L \& COMP. L. REV. 725, 729-33 (2008) (discussing the intersection of Post-Traumatic Stress Disorder and asylum credibility determinations).

178. See Kang v. Attorney Gen. of the U.S., 611 F.3d 157, 167 (3d Cir. 2010) (admonishing the government's appeal by stating that "[i]t is disappointing, even shocking, that the government fails to acknowledge that the evidence... compels the conclusion that [the applicant] will likely be tortured," as well as by reminding the government that "it is duty-bound to 'cut square corners' and seek justice rather than victory”); Lance Jolley, Where O' Where Has the Eleventh Circuit Gone? An Exploratory Analysis of the Declining Percentage of Published Asylum-Related Wins, IMMIGR. LITIG. BULL., June 2010, at 3, http://www.justice.gov/civil/oil/ImmigrationBulletin/June_2010.pdf (analyzing the decline of the government's "win rate" in an article by a government attorney that appeared in a publication of the Office of Immigration Litigation of the Department of Justice); Merjian, supra note 174, at 668 ("[Government] lawyers have assumed fully adversarial roles, fighting asylum claims vigorously, regardless of their merit. 'Before $9 / 11$, we used to be able to negotiate with [the government], and work something out in a case like this,' said one member of [an asylum applicant's] legal team, 'but post-9/11, their lawyers try to cream you.'”).

179. Kang, 611 F.3d at 167.

180. See APPLESEED, supra note 25, at 4 (recommending that government immigration attorneys be reminded "that their mission is to enforce the law as written, not to deport every immigrant").

181. In its annual report, U.S. Immigration and Customs Enforcement highlighted its attorneys' "vital role" in removal and touted that "ICE attorneys obtained 91,374 final orders of removal." U.S. IMMigRATION AND CUSTOMS ENFORCEMENT, ICE FisCAL YEAR 2008 ANNUAL REPORT: PRotecting NATIONAL SECURity AND UphOLding PUBlic SAFETy 28 (2008), available at http://www.ice.gov/doclib/news/library/reports/annual-report/2008annual-report.pdf.

182. See APPLESEED, supra note 25, at 16 ("Many of our interviewees believe that [government immigration attorneys] face extreme pressure to remove from the United States every person who 
the removal proceeding is a civil proceeding, the hearing plays out like a head-to-head battle where the noncitizen's interests are viewed as inherently opposed to the government's interests.

Adding to the criminal-like tone is the fact that half of immigration court hearings take place while the foreign national is in detention. ${ }^{183}$ This feature only adds to the feeling of a criminal trial, despite, again, that the proceeding is officially civil. To make matters worse, the adjudication system increasingly relies on video hearings, where the noncitizen appears through closed-circuit television. ${ }^{184}$ These "defendants" have the added disadvantage of appearing to the immigration judge as a grainy, two-dimensional image.

Creating more independent adjudicators may partially resolve this conflicting signal. An independent immigration judge corps may send a clearer signal that the proceeding is, in fact, designed to be held in a neutral forum. But this change will not necessarily address how the government prosecutes these cases or the foreign national's growing resemblance to a criminal defendant.

\section{The Lack of De Facto Independence for Immigration Adjudicators}

Independence from the Attorney General carries the promise of increased decisional independence. Removed from any other executive agency, immigration adjudicators could objectively adjudicate cases without fear of politically motivated repercussions. This promise, however, may not be fulfilled if immigration adjudicators are not given a prerequisite to independence: better working conditions that will allow immigration adjudicators to achieve de facto independence. ${ }^{186}$ More specifically, immigration adjudicators need smaller caseloads, more law clerks, and more training.

comes before an Immigration Court, even if there is scant basis for doing so.”).

183. Half of the cases completed by the immigration courts in fiscal year 2009 involved detained foreign nationals. EXEC. OFFICE FOR IMMIGRATION REVIEW, supra note 127, at O1.

184. See Developments in the Law-Access to Courts, 122 HARV. L. REV. 1151, 1181 (2009); see also OFFICE OF THE CHIEF IMMIGRATION JUDGE, supra note 176, § 4.7, at 58-59.

185. See Developments in the Law-Access to Courts, supra note 184, at 1184-88 (discussing the disadvantages of appearing in immigration court via video).

186. Current proposals for structural reform acknowledge the need for increased resources to immigration adjudicators. See ABA STUDY, supra note 11, at ES-28; APPLESEED, supra note 25, at 10-12, RAMJI-NOGALES ET AL., supra note 25, at 100-18; Legomsky, supra note 25, at 1640, 165157; Marks, supra note 12, at 8-9. 
As explained above, caseloads are simply too high. ${ }^{187}$ To meet this growing demand, an immigration judge is on his or her own. While there are law clerks, each law clerk works for about four immigration judges. ${ }^{188}$ With little support, immigration judges must face pro se litigants in over sixty percent of their cases. ${ }^{189}$ In attempting to manage an impossible docket, immigration judges are wearing themselves out. According to a recent study, immigration judges scored higher on a burnout test than any other professional group, including prison wardens. $^{190}$

The system demands too much from its adjudicators. As the above discussion reveals, the substantive law is extremely complex, and adjudications involve complex factual issues as well. Immigration judges often hear claims for asylum. Again, in an asylum case, immigration judges must not only apply the complex statutory, regulatory, and subregulatory framework, but must also make factual determinations on country conditions and the credibility of the applicant's claim. These cases require an immigration judge not only to be an expert on the law, but also on the social and political conditions and cultural norms of any given country. Familiarity with cultural norms allows an immigration judge to make credibility determinations by measuring an applicant's demeanor against the applicant's own cultural norms. Also, because credibility is determinative, adjudication requires an actual hearing that lasts at least half of a day and probably longer. For an immigration judge to keep up with the docket, it would not be possible to provide the type of in-depth attention that should be paid when the claim itself alleges that the claimant has a well-founded fear of persecution in the home country. In fact, one court of appeals judge has explained that under these kinds of working conditions, "[i]mmigration judges simply cannot be expected to make thorough and competent findings of fact and conclusions of law."

To compound the problem, immigration judges are often left on their own to keep up with the fast-changing intricacies of immigration law,

187. See supra Part III.B.1.d.i.

188. Transactional Records Access Clearinghouse, Case Backlogs in Immigration Courts Expand, Resulting Wait Times Grow (June 18, 2009), http://trac.syr.edu/immigration/reports/208/.

189. See Markowitz, supra note 106, at 544-45 (acknowledging the burden of pro se representation on immigration judges); supra notes 139-40 and accompanying text.

190. Stuart L. Lustig et al., Inside the Judges' Chambers: Narrative Responses from the National Association of Immigration Judges Stress and Burnout Survey, 23 GEO. IMMIGR. L.J. 57, 60 (2008).

191. Immigration Litigation Reduction: Hearing Before the S. Comm. on the Judiciary, 109th Cong. 6 (2006) (statement of C.J. John M. Walker, Chief Judge, U. S. Court of Appeals for the Second Circuit). 
with little group training. ${ }^{192}$ De facto independence depends on sufficient time to stay abreast of the law and to deepen one's skills and understanding of the law. The lack of training opportunities is linked to the overwhelming dockets. While recognizing efforts to improve training, Dana Marks, the President of the National Association of Immigration Judges, has called such improvements "practically meaningless when those they are meant to benefit do not have any time actually provided to put them to use." ${ }^{„ 193}$ Due to the need to keep deciding cases at a fast clip to try to keep up with the docket, immigration judges do not have time to train. It is constantly game day for these immigration judges. Such pressure has led immigration judges to describe their role as simply a part of an immigration law factory. ${ }^{194}$

The lack of sufficient resources at the Board of Immigration Appeals is best exemplified by the "streamlining" regulations expanded under Attorney General John Ashcroft. ${ }^{195}$ Ashcroft's response to a large backlog of 56,000 cases at the Board was to forbid Board members from providing any reasons for their decisions in large categories of cases. ${ }^{196}$ Instead, Board members were required to issue an "Affirmance Without Opinion," which contained only two sentences of boilerplate language. ${ }^{197}$ Ashcroft also reacted to the backlog by shrinking the membership of the Board and then, in turn, requiring more single member adjudications, rather than three-member panel adjudications. ${ }^{198}$

The paucity of resources for immigration judges and the streamlining reforms exemplify the danger of underfunded adjudication. Even if reform would eliminate the role of the Attorney General in dictating how

192. Attorney General Alberto Gonzales proposed more training in 2006. EOIR Reports Progress in Implementing Reforms, 84 INTERPRETER RELEASES 885, 886 (2007). In 2008, only a virtual training conference took place. RAMJI-NOGALES ET AL., supra note 25, at 110. Participating immigration judges gave the virtual training low marks. Id.

193. Marks, supra note 12, at 13.

194. Stuart L. Lustig et al., Burnout and Stress Among United States Immigration Judges, 13 BENDER's IMMIGR. BULL. 22, 30 (2008).

195. See Board of Immigration Appeals: Procedural Reforms to Improve Case Management, 67 Fed. Reg. 7309, 7310-13 (proposed Feb. 19, 2002) (to be codified at 8 C.F.R. pts. 3, 280); see also Board of Immigration Appeals: Procedural Reforms to Improve Case Management, 67 Fed. Reg. 54,878, 54,880 (Aug. 26, 2002) (to be codified at 8 C.F.R. pt. 3).

196. See Board of Immigration Appeals: Affirmance Without Opinion, Referral for Panel Review, and Publication of Decisions as Precedents, 73 Fed. Reg. 34,654, 34,656 (proposed June 18, 2008) (to be codified at 8 C.F.R. pt. 1003) (describing Ashcroft's actions in 2002).

197. Board of Immigration Appeals: Procedural Reforms to Improve Case Management, 67 Fed. Reg. at 7315; see also Board of Immigration Appeals: Procedural Reforms to Improve Case Management, 67 Fed. Reg. at 54,903.

198. See Board of Immigration Appeals: Affirmance Without Opinion, Referral for Panel Review, and Publications of Decisions as Precedents, 73 Fed. Reg. at 34,655-56. 
to allocate insufficient resources, the problem of insufficient resources would not disappear. Immigration adjudicators need adequate time and support to perform their adjudicatory function. De facto independence demands more than just decisional independence-it demands the resources that will allow immigration adjudicators to benefit from the positive change in status.

\section{Diversions from Immigration Adjudication}

Imagine an immigration adjudication system filled with independent, able adjudicators who apply the law to the facts with the time and resources to consider thoughtfully each matter. Now imagine a scenario where this desirable system exists, but immigration enforcement officials are authorized to choose who gets access to it. Any gains of decisional independence would be stymied by a gatekeeping function that could keep an improved system out of reach for large classes of noncitizens. This is the danger of the immigration adjudication diversion. Through a diversion, the executive branch is permitted to make end-runs around the entire system. $^{199}$

Diverted individuals never access the immigration adjudication system, no matter its state. Instead, these individuals are subject to a shadow adjudication process that avoids the procedures and protections of the formal system. Each year, the government completes millions of diversions from the immigration adjudication system. ${ }^{200}$ There are many manifestations of this phenomenon. I describe three here: the adjudication waiver of the Visa Waiver Program; stipulated orders of removal; and a proposed adjudication waiver linked to legalization. ${ }^{201}$

Under the Visa Waiver Program, certain noncitizens are able to travel to the United States on a temporary basis without a visa. ${ }^{202}$ The advantage to the noncitizen is that the program eliminates the need to complete the visa application process abroad. Instead, the noncitizen travels to the United States with his or her visa-less passport. ${ }^{203}$ Upon arrival, a frontline border officer decides whether each applicant under

199. I have previously categorized and examined the numerous ways that the government may divert foreign nationals from the immigration adjudication system. Family, supra note 4.

200. Id. at $612-13$.

201. I have previously described these and other types of diversions. See id. at 611-32. The ABA Study discusses the use of expedited removal and administrative removal of aggravated felons. ABA STUDY, supra note 11, at ES-23 to -24.

202. 8 U.S.C. § 1187(a), (c) (2006 \& Supp. III 2009).

203. See 8 U.S.C. § 1187(a) (2006). 
the program is admissible to the United States. ${ }^{204}$ This involves applying the statutory framework that provides grounds of inadmissibility (such as certain criminal convictions and previous immigration violations). ${ }^{205}$ In exchange for the elimination of the visa requirement, the program extracts a waiver of adjudication rights. ${ }^{206}$ Noncitizens participating in the program must waive any right to challenge the border officer's determination as to their admissibility ${ }^{207}$ but must also prospectively waive any right to challenge a future attempt to remove the noncitizen from the United States, unless the noncitizen has a claim for asylum. ${ }^{208}$ In fiscal year 2008, over seventeen million admissions took place under the program. ${ }^{209}$ Each admission carries a waiver of adjudication rights. Thus, for participants in the Visa Waiver Program, independent adjudicators have no impact, unless the noncitizen has an asylum claim, because the program's mandatory waiver prevents participants from accessing the immigration adjudication system.

The second diversion example is a stipulated order of removal. By stipulating to removal, a noncitizen eliminates the need for an adjudication to determine removability or to apply for relief. ${ }^{210}$ A noncitizen who stipulates to removal therefore waives access to the immigration adjudication system. In 2008, it was estimated there would

204. 8 C.F.R. § 217.4(a)(1) (2010).

205. Id.

206. 8 U.S.C. $\S 1187(\mathrm{~b})$.

207. Id. § 1187(b)(1), (g); see also 8 C.F.R. § 217.4(a)(1) ("Such refusal and removal shall be made at the level of the port director or officer-in-charge, or an officer acting in that capacity, and shall be effected without referral of the alien to an immigration judge for further inquiry, examination, or hearing, except [for] an alien who presents himself or herself as an applicant for admission under section 217 of the Act and applies for asylum in the United States ....”).

208. 8 U.S.C. § 1187(b)(2); see also 8 C.F.R. § 217.4(b)(1) (“Such removal shall be determined by the district director who has jurisdiction over the place where the alien is found, and shall be effected without referral of the alien to an immigration judge for a determination of deportability, except [for] an alien who was admitted as a Visa Waiver Program visitor who applies for asylum in the United States ....").

209. RANDAll Monger \& MACReadie BarR, DHS OfFice of IMMigration Statistics, NONIMMIgRANT ADMISSIONS TO THE UNITED STATES: 2008, at 7 tbl.9 (2009), available at http://www.dhs.gov/xlibrary/assets/statistics/publications/ois_ni_fr_2008.pdf. The Office of Immigration Statistics reported the number of admissions, which does not coincide with the number of individuals using the Visa Waiver Program because an individual could be admitted more than once in a fiscal year. Id. at 2. Also, these numbers refer only to admissions and do not include those rejected admission at the border. Id. For instance, in May 2008, a Customs and Border Patrol spokesperson indicated that in the seven months prior, 3300 applicants had been rejected under the Visa Waiver Program and more than eight million had been admitted. Nina Bernstein, Italian's Detention Illustrates Dangers Foreign Visitors Face, N.Y. TIMES, May 14, 2008, at A14.

210. 8 C.F.R. § 1003.25(b). 
be approximately 35,000 stipulated removals. ${ }^{211}$ As with Visa Waiver Program participants, any improvements to the immigration adjudication system are meaningless to a noncitizen who never accesses the system due to a stipulation that the individual is removable. If the stipulation is the product of real, fair negotiation, the waiver of access may not be troublesome. The government's implementation of stipulated orders of removal, however, raises serious concerns when measured against basic principles of administrative process design. ${ }^{212}$ If government coercion, misinformation, or a lack of information is motivating a noncitizen's agreement to removal, that implicates not only how the diversion fares under basic principles of administrative process design, but also highlights how, through such a diversion, the government could deflect noncitizens from an improved immigration adjudication system.

While not yet law, a proposed adjudication waiver linked to legalization is the third example provided here because it perhaps represents a new type of diversion-the no-option waiver. The U.S. Senate endorsed an adjudication waiver as a condition to legalize immigration status. ${ }^{213}$ Under the Senate bill, the application for legalization would have included a waiver of adjudication rights. To apply, one would be required to waive "any right to judicial review or to contest any removal action, other than on the basis of" asylum, withholding of removal, relief under the Convention Against Torture, or certain relief provided by Cancellation of Removal. ${ }^{214}$ Because the waiver is an application requirement, there really is no waiver-free alternative, which makes this proposed waiver a no-option waiver. An estimated twelve million individuals reside in the United States without permission. ${ }^{215}$ If a no-option adjudication waiver is enacted as a part of any legalization program, it would affect millions. For purposes of improving immigration adjudication, this concept is dangerous because it could start a trend of requiring waivers to adjudication in exchange for immigration benefits. If such a trend develops, an improved immigration adjudication system would be meaningless to those required to waive access to it.

211. JAYAShri SRIKANTiah \& Karen Tumlin, Backgrounder: STIPUlated Removal 1 (2008), http://www.nilc.org/immlawpolicy/removpsds/stipulated-removal-bkgrndr-2008-11.pdf.

212. See Family, supra note 4, at 642-43, 645-46.

213. Immigrant Accountability Act of 2006, S. 2611 ES, 109th Cong. § 601(b) (2006) (adding $\S 245 \mathrm{C}(\mathrm{b})(7)(\mathrm{C}))$.

214. Id.

215. Gabriel Escobar, The Complex Tapestry of the Undocumented: Day Laborers Are Just One Strand, Pew ReSEARCH CenTeR (Mar. 28, 2006), http://pewresearch.org/pubs/14/the-complextapestry-of-the-undocumented. 
To ensure that improvements to immigration adjudication are not so restricted as to render them meaningless to large numbers of noncitizens, proposals to reform immigration adjudication must consider the practical effect of diversions from immigration adjudication. Reforms must take care to integrate restrictions on the government's use of such diversions so that diversions do not effectively neuter any improvements to the immigration adjudication system, including greater decisional independence.

\section{Weakened Judicial Review}

The federal courts do not have jurisdiction to review all of the output of this troubled administrative adjudication system. There are three types of limits on federal court jurisdiction: substantive; timing; and form. The substantive restrictions carve out whole classes of decisions from judicial review. For example, there are restrictions on jurisdiction to review discretionary decisions and to review removal orders based on criminal convictions. ${ }^{216}$ One timing restriction shortens the period within which a foreign national could seek judicial review. ${ }^{217}$ One type of form restriction eliminates certain types of immigration class actions. ${ }^{218}$

Despite the narrowing of the federal courts' jurisdiction over immigration cases, courts of appeals have expressed deep concern with the quality of the output of the administrative adjudication process through their review of those cases where jurisdiction remains. The courts of appeals mostly hear asylum cases, and those cases give plenty of examples of dissatisfaction with the work of the Board of Immigration Appeals and of immigration judges. Courts of appeals have issued opinions identifying immigration judges' biases towards foreign nationals, intimidating and demeaning behavior towards foreign nationals, and poor legal analysis. ${ }^{219}$ Judge Richard Posner of the Court

216. 8 U.S.C. § 1252(a)(2)(B)-(C) (2006).

217. Id. § 1252(b)(1).

218. Id. § 1252(e)(1).

219. See, e.g., Ayala v. U.S. Attorney Gen., 605 F.3d 941, 943 (11th Cir. 2010) (“The decision of the Board [of Immigration Appeals] is riddled with error.”); Tekle v. Mukasey, 533 F.3d 1044, 1052 (9th Cir. 2008) (finding the immigration judge's adverse credibility finding was not supported by substantial evidence); Ali v. Mukasey, 529 F.3d 478, 492-93 (2d Cir. 2008) (concluding that prior proceedings were fundamentally unfair); Kaita v. Attorney Gen. of the U.S., 522 F.3d 288, 301 (3d Cir. 2008) (noting the "antagonistic manner" of the immigration judge's interruptions); Floroiu v. Gonzales, 481 F.3d 970, 976 (7th Cir. 2007) (stating that the immigration judge's handling of the case "denied [the foreign national's] right to be heard"); Wang v. Attorney Gen. of the U.S., 423 F.3d 260, 270-71 (3d Cir. 2005) (criticizing the immigration judge's "contemptuous tone” and consideration of irrelevant personal judgments); Recinos de Leon v. Gonzales, 400 F.3d 1185, 1193 
of Appeals for the Seventh Circuit wrote in a 2005 opinion that immigration adjudication had fallen "below the minimum standards of legal justice."220

The federal courts are implicated in the immigration adjudication crisis beyond their role in highlighting the lapses in the quality of administrative decision-making. The federal courts, perhaps counterintuitively given the cuts in jurisdiction, have also seen huge increases in the numbers of immigration appeals filed in the courts of appeals. In fiscal year 2001, 1760 appeals from decisions of the Board were filed in the courts of appeals. ${ }^{221}$ By fiscal year 2003, the number filed reached $8833,{ }^{222}$ and the number rose to 12,349 appeals filed in fiscal year 2005..$^{223}$ By 2009, the number dropped to 7518, but that number is still high compared to 2001 levels, and Board appeals make up roughly eighty-eight percent of all administrative appeals in the courts of appeals. $^{224}$

Granting decisional independence to administrative adjudicators would not address the problems presented by a lack of judicial review. In fact, a key to the success of the administrative adjudication component of the system is the existence of more robust judicial review. More recent proposals for immigration adjudication reform recognize this, ${ }^{225}$ while some older proposals argued that strengthened administrative review served as a justification for decreasing the role of the federal courts. ${ }^{226}$ Others have discussed the benefits and costs of judicial review in immigration adjudication. ${ }^{227}$ This discussion focuses on the role of

(9th Cir. 2005) (criticizing the immigration judge’s “lack of coherent explanation”).

220. Benslimane v. Gonzales, 430 F.3d 828, 830 (7th Cir. 2005); see also Lynne Marek, Posner Blasts Immigration Courts as 'Inadequate' and Ill-Trained, NAT'L L.J., Apr. 22, 2008, available at http://www.law.com/jsp/article.jsp?id=1208861007986.

221. AdMin. OfFice OF the U.S. COURTS, JUdiCIAL BusinesS OF THE U.S. COURTS 114 tbl.B-3 (2005), available at http://www.uscourts.gov/uscourts/statistics/JudicialBusiness/2005/appendices/ b3.pdf.

222. Id.

223. Id.

224. Admin. OfFice Of the U.S. Courts, Judicial Business of the U.S. COURTS 94 tbl.B-3 (2009), available at http://www.uscourts.gov/Statistics/JudicialBusiness/JudicialBusiness.aspx?doc= /uscourts/Statistics/JudicialBusiness/2009/appendices/B03Sep09.pdf.

225. See, e.g., Legomsky, supra note 25, at 1696.

226. See, e.g., Maurice A. Roberts, Proposed: A Specialized Statutory Immigration Court, 18 SAN DIEGO L. REV. 1, 19-20 (1980).

227. See, e.g., STEPHen H. Legomsky, IMMigRation AND the Judiciary: LAW AND Politics IN BRITAIN AND AMERICA 272-80 (1987); Benson, Making Paper Dolls, supra note 60, at 63-64; Stephen H. Legomsky, Fear and Loathing in Congress and the Courts: Immigration and Judicial Review, 78 TEX. L. ReV. 1615, 1628-31 (2000) [hereinafter Legomsky, Fear and Loathing]; Stephen H. Legomsky, Political Asylum and the Theory of Judicial Review, 73 MinN. L. REv. 1205, 1209-16 (1989); Martin, supra note 156, at 1361-63. 
judicial review in the context of reforming administrative adjudication. ${ }^{228}$ This discussion leaves aside constitutional questions raised by the elimination of judicial review and instead focuses on what the existence and nature of judicial review means for the functioning of the whole adjudication system.

Judicial review is a key to success for improvement of the immigration adjudication system for several reasons. First, judicial review helps to boost immigration esteem. Second, judicial review is essential to a more efficient system. Third, judicial review increases the legitimacy of the entire adjudication system.

Judicial review is essential to the success of immigration adjudication reform because of the immigration esteem problem discussed above. ${ }^{229}$ Narrowing judicial review reinforces the stereotype of immigration law as a lesser field. It confines the legal practice to administrative adjudication and eliminates the prestige of practice before federal courts of appeals. ${ }^{230}$ It also sends the signal that the field is not important. After all, if Congress does not think these litigants worthy to access the federal courts, it sends a signal that these litigants and this type of litigation are not worthy of attention. Also, if the practice is relegated to a dysfunctional administrative system where there is no hope of judicial review, that demotion may further discourage attorneys from entering the field.

A more efficient system depends on robust judicial review. Critics of judicial review in immigration cases label it a source of delay in the adjudication system. ${ }^{231}$ Subscribers to this theory believe that immigration litigants are motivated by delay and therefore judicial

228. The administrative adjudication components and judicial review are mutually dependent. See Stephen H. Legomsky, Forum Choices for the Review of Agency Adjudication: A Study of the Immigration Process, 71 IowA L. REV. 1297, 1299 (1986) (arguing that "administrative review and judicial review should be seen as parts of a single, continuous, adjudication process"); Richard L. Revesz, Specialized Courts and the Administrative Lawmaking System, 138 U. PA. L. REV. 1111, 1114, 1144 (1990) (defining the "administrative lawmaking system" to include administrative and judicial review); Paul R. Verkuil, A Study of Immigration Procedures, 31 UCLA L. REV. 1141, 1179 (1984) (discussing the dependent relationship between administrative and judicial review in the context of due process analysis).

229. See supra Part III.B.1.d.iii.

230. Perceived prestige characteristics of the courts of appeals include superior decision-making, geographically expansive jurisdiction and higher quality judges. See Currie \& Goodman, supra note 163, at 12; see also Colyer et al., supra note 143, at 470-71 (reporting "widespread interest in representing immigrants before the Second Circuit where needed, in any type of case").

231. See Jill E. Family, Stripping Judicial Review During Immigration Reform: The Certificate of Reviewability, 8 NEV. L.J. 499, 521-22 (2008). 
review is an invitation to delay deportation. ${ }^{232}$ While eliminating unnecessary delays would increase the efficiency of immigration adjudication, not all delays are necessarily inefficient. Efficiency indicates not just that the job is being done but that it is being done as quickly as possible while maintaining an acceptable level of quality. Efficiency concerns are not an excuse to do less of a job and to mislabel any resulting time-savings as efficiency gains. Not all time savings are true efficiency gains if quality diminishes to an unacceptable level. After all, a car without an engine would be more fuel efficient (it uses less fuel-none!), but the car now fails to do its job. In actuality, a car is more efficient when it performs its purpose but does so with less fuel.

Looking at the efficiency of the immigration adjudication system in the true sense of that word reveals that judicial review plays a key role in the efficient operation of the system. If the system is to perform the job "in the best possible manner with the least waste of time and effort" while also in a "competent" manner, judicial review must contribute. ${ }^{233}$ Judicial review is not a waste of time and effort.

There is ample evidence that eliminating judicial review has not led to a system that competently performs "in the best possible manner with the least waste of time and effort." First, the system has been operating since 1996 without judicial review over many key issues and kinds of immigration cases. ${ }^{234}$ The absence of judicial review has not cured the system of its problems. In fact, the restrictions on judicial review have caused new forms of litigation that simply detract or delay participants from litigating the issues at the heart of their case. As Professor Lenni Benson has argued, stripping judicial review creates litigation over the court's jurisdiction. ${ }^{235}$ This is not efficient. What would be efficient would be to litigate the substantive issues with the least waste of time and effort, rather than to argue about the meaning and constitutionality of the jurisdiction-stripping provisions.

Second, a historical, pre-1996, narrowing of immigration judicial review also did not extinguish calls for reform of the system. There was a time when deportation orders followed a judicial review path that

232. See id.

233. See Define Efficient, DiCTIONARY.COM, http://dictionary.reference.com/browse/efficient (last visited Jan. 9, 2011); see also Verkuil, supra note 228, at 1179 (arguing that appellate review plays a role in establishing the legitimacy of the hearing process).

234. See Family, supra note 4, at 608-09.

235. Benson, Making Paper Dolls, supra note 60, at 41; see also HENRY J. FRIENDLY, FEDERAL JURISDICTION: A GENERAL VIEW 175-76 (1973) (arguing that narrowing immigration judicial review to direct appeal to the courts of appeals generated its own litigation). 
included both district court and court of appeals review. ${ }^{236}$ Congress eliminated the role of the district courts in 1961 in response to concerns about how long it took to effectuate a deportation order. ${ }^{237}$ This reform set the stage for further narrowing in 1996, which was similarly justified by delay concerns. ${ }^{238}$

Third, the streamlining experiment at the Board is also evidence that eliminating review is not truly efficient. When the Board ceased to provide reasoned decisions in large categories of cases, litigants did not shrug their shoulders and walk away. Instead, they sought out available alternative litigation opportunities, such as review in the federal courts. ${ }^{239}$ Thus, the work simply shifted to other locales. As one observer aptly commented, the streamlining experiment led to a "false economy."240 The Board stopped performing its function, which is different from performing its function "with the least waste of time and effort." The experience of the streamlining regulations shows that eliminating a layer of review is not itself efficient both because it merely diverted litigation and because quitting is not what defines efficiency. A prerequisite to greater efficiency is that one must actually do the job.

Judicial review, in fact, is the mechanism to make sure the administrative review components are doing their job. Judicial review can perform this function through its oversight role. ${ }^{241}$ Critics who truly desire a more efficient system (rather than a system that just provides less) should embrace the possibilities of judicial review. After all, judicial review can be deferential while still existing as a check on administrative adjudicators.

At the same time, this oversight role increases the legitimacy of the administrative review component. Oversight is important not only because adjudicators at the administrative level will know that a case is subject to review, but also because the supervision sends a signal to litigants and to the public that someone is keeping an eye on the system. This role of the federal courts has been diminished, but not eliminated, since 1996. Courts of appeals have taken the lead in pointing out

236. Stephen H. Legomsky \& CRistina M. Rodríguez, ImMigRation and REFUgeE LaW AND POLICY 756-57 (5th ed. 2009).

237. Id.

238. See id.

239. See Family, supra note 231, at 504-05.

240. Marks, supra note 12, at 9.

241. See Legomsky, Fear and Loathing, supra note 227, at 1631; Revesz, supra note 228, at 1144. 
deficiencies at the administrative level. ${ }^{242}$ However, because courts of appeals only see a limited slice of the output of administrative adjudication, no one oversees those decisions that are not subject to review. If the quality of adjudication is low in the cases immigration judges and the Board know a court of appeals may see, what is the quality of those decisions these adjudicators know to be exempted from review? ${ }^{243}$ Without judicial review, the answer to that question remains unknown, leaves room for doubt, and raises suspicion. If Congress narrows judicial review further, it would silence the main existing mechanism for shedding light on the status of administrative adjudication. After all, if Congress had eliminated all judicial review in 1996, it would have prevented courts of appeals from discovering the inadequacies of administrative adjudication since then.

Greater decisional independence for administrative adjudicators could lead to a more respected administrative review process, which could make the entire system more efficient. If decisions of the administrative review process are more acceptable, fewer appeals to the federal courts may be necessary. ${ }^{244}$ As the system stands now, immigration litigants view court of appeals judges with confidence, but they are the only actors in the adjudication system that receive such respect. $^{245}$ In a pyramid adjudication system, the administrative review levels should filter cases so that only the most novel and complicated issues reach the judicial review stage. If the administrative review process occasionally breaks down and performs subpar, then the judicial review stage can catch such errors. Because the administrative components of the system are viewed as permanently broken, litigants have motivation to appeal everything, with the hope that the federal courts will give the case a thoughtful, reasoned look. There is no reason why the first thoughtful, reasoned look should wait until the court of appeals.

The detriment of subpar administrative adjudication is visible through the decisions of courts of appeals. For example, after eight years in litigation, the immigration case of $\mathrm{Hu} v$. Holder remained

242. See infra notes 219-20 and accompanying text.

243. See Martin, supra note 156, at 1365 (discussing the positive influence of judicial review on agency self-policing).

244. See Legomsky, supra note 228, at 1332 ("Administrative review will sometimes eliminate a party's need to resort to more costly judicial review.”).

245. See Marks, supra note 12, at 8 (describing a link between the cynicism towards administrative adjudicators and the increased immigration dockets in courts of appeals). 
unresolved. $^{246}$ The Court of Appeals for the Second Circuit has remanded this case twice. The first time, after an affirmance by the Board, the Second Circuit remanded the case on the ground that the immigration judge's order consisted of "unspecified inconsistencies, flawed reasoning and misunderstanding of evidence."247 On remand, four years after the original hearing, the immigration judge attempted to clarify the original decision. ${ }^{248}$ In so doing, the immigration judge raised, for the first time, doubts about the applicant's credibility based on her demeanor. ${ }^{249}$ After another Board affirmance, the case worked its way back to the Second Circuit. ${ }^{250}$ The Second Circuit could not affirm the immigration judge's "clarified" decision under the substantial evidence standard because, among other things, it was incredulous that this immigration judge could so clearly remember the applicant's demeanor four years later, especially when the original opinion made no mention of the applicant's demeanor. ${ }^{251}$ The Second Circuit stated: "No evidence in the record suggests that these analyses are based on anything but the [immigration judge's] recollection of Hu's demeanor when she testified nearly four years before." 252 Referencing the "onerous" caseloads of immigration judges, the court concluded that "a reasonable adjudicator would not rely on his four year old memory." 253 So, in 2009, the Second Circuit found itself remanding this case for a second time, recommending that the case be assigned to a different immigration judge due to the poor quality of adjudication. ${ }^{254}$ The poor quality of adjudication has caused this case to chew up the time of the Second Circuit, as well as leaving the applicant's immigration status in limbo for over eight years.

While decisional independence may attract better adjudicators, which in turn may lower the burden on the federal courts, it is important to remember the other hurdles to improve administrative adjudication discussed here. Decisional independence alone will still leave a troubled administrative adjudication system. That troubled system will continue to cry out for federal court supervision. Even if all of what ails

246. Hu v. Holder, 579 F.3d 155 (2d Cir. 2009). Hu first applied for asylum on July 31, 2001. Id. at 157 .

247. Hu v. Gonzales, 160 Fed. App’x 98, 101-02 (2d Cir. 2005).

248. $\mathrm{Hu}, 579 \mathrm{~F} .3 \mathrm{~d}$ at $157-58$.

249. Id.

250. Id. at 158.

251. Id. at $158-59$.

252. Id.

253. Id. at 159.

254. Id. at 160 . 
administrative adjudication is cured, the system still needs judicial review to promote efficiency, to perform its oversight role, to lend legitimacy to the system, and to ease immigration law's esteem problem.

\section{CONCLUSION}

This Article reveals the complicated dynamics of the immigration adjudication crisis. A lack of decisional independence does contribute to the crisis, but there are other substantial contributors. The complicated dynamics of the crisis are revealed by examining five contributors to the crisis other than a lack of decisional independence. First, substantive immigration law is a contributor to the crisis, as it contributes to the huge backlogs in the system, the extreme lack of lawyers in the system, and immigration law's esteem problem. Second, the conflicting signals of the system hold it back by confusing any sense of mission. The creation of more independent adjudicators will not resolve all of these conflicting signals. Third, de facto independence for immigration adjudicators is crucial because a position that carries formal decisional independence does not come with a guarantee that the position will carry the resources necessary to allow effective use of that status. Fourth, the growing use of diversions from immigration adjudication threatens the usefulness of any improvements to immigration adjudication. For a diverted foreign national with no access to the adjudication system, the state of that system is less relevant. Fifth, the system requires more robust judicial review, no matter the job security of its administrative adjudicators.

While a lack of decisional independence is a major shortcoming, this Article shows that creating more independent immigration adjudicators will not address all of the system's deficiencies. Fixing administrative adjudication is a complicated task, and a magic bullet is elusive. 